Article

\title{
Impacts of the FLEGT Action Plan and the EU Timber Regulation on EU Trade in Timber Product
}

\author{
Paul Rougieux *(D) and Ragnar Jonsson \\ European Commission, Joint Research Center (JRC), Directorate D—Sustainable Resources, Bio-Economy, \\ Via E. Fermi 2749, I-21027 Ispra, Italy; ragnar.jonsson@ec.europa.eu \\ * Correspondence: paul.rougieux@ec.europa.eu
}

Citation: Rougieux, P.; Jonsson, $\mathrm{R}$. Impacts of the FLEGT Action Plan and the EU Timber Regulation on EU Trade in Timber Product. Sustainability 2021, 13, 6030. https:// doi.org/10.3390/su13116030

Academic Editor:

Pierfrancesco De Paola

Received: 30 April 2021

Accepted: 24 May 2021

Published: 27 May 2021

Publisher's Note: MDPI stays neutral with regard to jurisdictional claims in published maps and institutional affiliations.

Copyright: (c) 2021 by the authors. Licensee MDPI, Basel, Switzerland. This article is an open access article distributed under the terms and conditions of the Creative Commons Attribution (CC BY) license (https:/ / creativecommons.org/licenses/by/ $4.0 /)$.

\begin{abstract}
The EU Timber Regulation (EUTR) is a key element in the efforts of the European Union to curb the trade in illegal timber products. This study helps to remedy the lack of systematic, statistical analysis of the EUTR's potential impacts on international trade in timber products. Using cointegration intervention-or shock-models we quantify potential shifts in import prices and quantities of tropical hardwood lumber and oak lumber after the entry into effect of the EUTR. We further estimate import demand models to assess the relation between temperate and tropical hardwood products and whether there was a structural change in demand elasticities after the entry into force of the EUTR. The shock model analysis indicates, for most of the bilateral trade flows where we observe cointegration and a significant shock variable, increasing import prices and decreasing import quantities of tropical hardwood lumber following the EUTR start date, consistent with a contraction of the supply of tropical timber. The results of the import demand models do not give a clear indication as to whether oak lumber is a complementary or substitute product for tropical hardwood lumber, and there are no clear signs of structural changes in demand elasticities. Aside from the analysis, an important contribution of the paper is the procedure for building a long and homogeneous time series of tropical hardwood lumber.
\end{abstract}

Keywords: illegal logging; trade; FLEGT; EUTR; time series econometrics; econometrics of panel data

\section{Introduction}

Illegal logging and the associated trade in timber products undermine legal timber trade and have detrimental environmental, economic, and social impacts [1]. The European Commission presented the Forest Law Enforcement, Governance, and Trade (FLEGT) Action Plan [2] as part of its endeavors to tackle illegal logging. Acknowledging the shared responsibility of exporters and importers, the objective is to eliminate illegal timber in international trade. A cornerstone of the FLEGT action plan is establishing Voluntary Partnership Agreements (VPAs) with timber producing and exporting countries, and the introduction of FLEGT-licensed timber [1]. A second key element of the plan is the EU Timber Regulation [3], which came into force on 3 March 2013. VPAs and the EUTR are meant to reinforce each other, addressing the supply (export) and demand (import) side of the timber product trade respectively (Figure 1).

A pertinent question then is what influences FLEGT and the EUTR, as well as other similar initiatives such as the US Lacey Act Amendment (LAA), have had on international trade in timber products. Estimates of the scale of illegal timber trade are surrounded by considerable uncertainty, since illegal trade is not recorded in trade databases [4]. Lawson and McFaul [5] — in assessing the effects of the LAA, FLEGT, and other efforts to reduce illegal logging through a combination of (i) surveys involving government officials, NGOs, and firms with (ii) the evaluation of trade and production data-found that illegal logging and exports of illegally sourced timber had decreased while timber product prices had risen since the beginning of the 2000s. Prestemon [6] performed econometric analysis on 
U.S. import data to assess the impact of the LAA. The results indicate general increases in prices and decreases in quantities of tropical hardwood imports to the U.S. from countries suspected of a high degree of illegal timber trade.

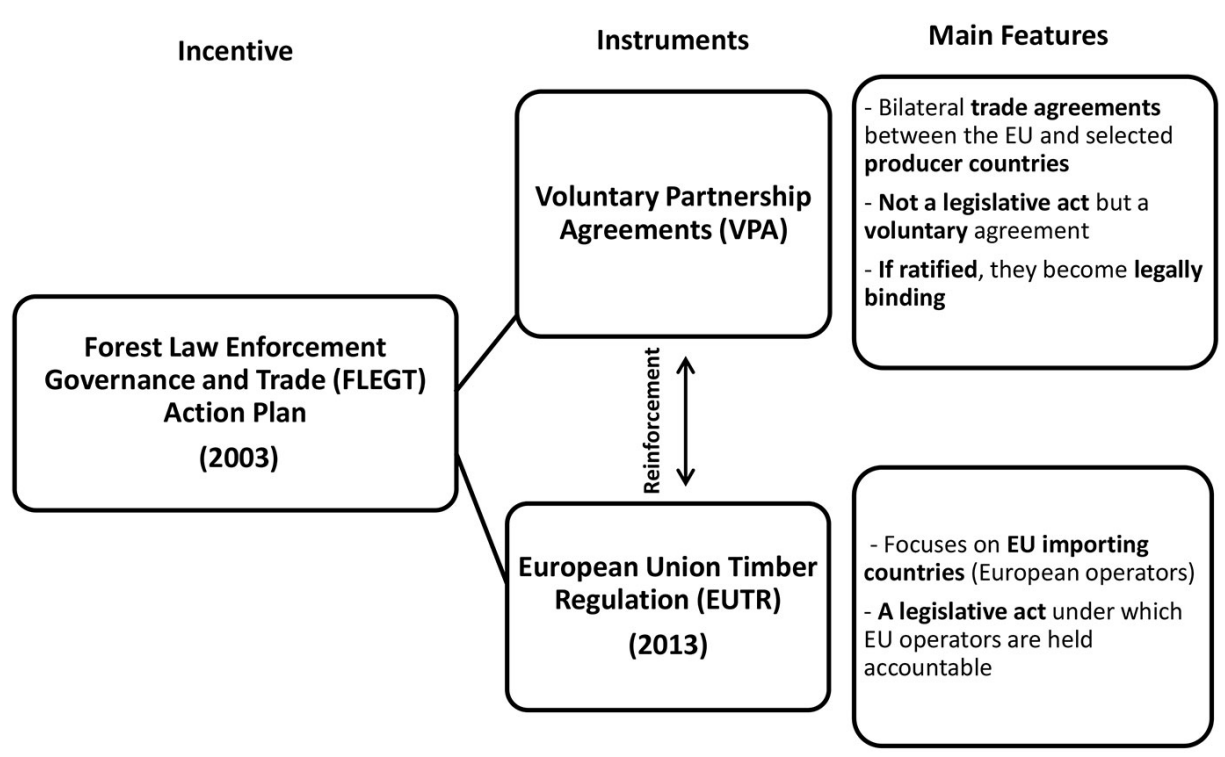

Figure 1. The FLEGT Action Plan with its two main instruments and their main features. Source: [7].

Due to the rather short time the EUTR has been in force, there are yet no studies that have performed systematic, comprehensive statistical analysis regarding the impacts on international trade in timber products. Anecdotal evidence suggests that the main reason for declining tropical timber demand in the EU is substitution by temperate timber [8,9]. The European flooring industry in particular has reported a significant fall in the use of tropical timbers, to a large extent attributed to environmental concerns [10]-illegal timber trade is primarily associated with tropical hardwood [11]. It is claimed that EUTR may have been key in reinforcing this trend, through increased costs of conforming to the requirements of the EUTR [7-9].

Figure 2 gives some support to this claim, illustrating shrinking imports of tropical hardwoods from extra EU countries while temperate hardwood imports are rather stable through time. In addition, Figure 2 reports on intra EU trade to highlight three facts and a limitation of the Comext database. First, the intra EU trade of other sawnwood is an order of magnitude higher than that of oak and tropical hardwood lumber (note the differences in scales). Second, the intra EU trade of oak lumber has been increasing dramatically in recent years. Third there is a stable intra EU trade of tropical hardwood lumber throughout the period, and the limitation of our data source is that there is only data on the European partner country for such trade flows, but not the original tropical country of production. The extra-EU imports that are then re-exported within the EU are not accounted for in our analysis. This is why aggregating the EU as a whole leads to loss of information. It is not an issue for the demand model since in that case we are not investigating the source of tropical timber but the overall consumption of tropical timber.

The objective of this study is to assess trade effects of FLEGT and the EUTR: Have the patterns of EU imports of hardwood timber products changed as a result of FLEGT and the EUTR? We address this overriding question by analyzing the effects of FLEGT and the EUTR on imported quantities and prices of selected hardwood products. To accomplish this, we use two classes of statistical models. Hence, we use cointegration intervention models to quantify potential shifts - corresponding with the implementation of the EUTR - in the cointegrating relations of import prices and quantities of tropical hardwood lumber and oak lumber respectively. In addition, we estimate an import demand model to assess the relation between temperate and tropical hardwood products, trying to 
establish whether they are substitutes or complements and analyzing whether there was a structural change in demand elasticities after the entry into force of the EUTR.

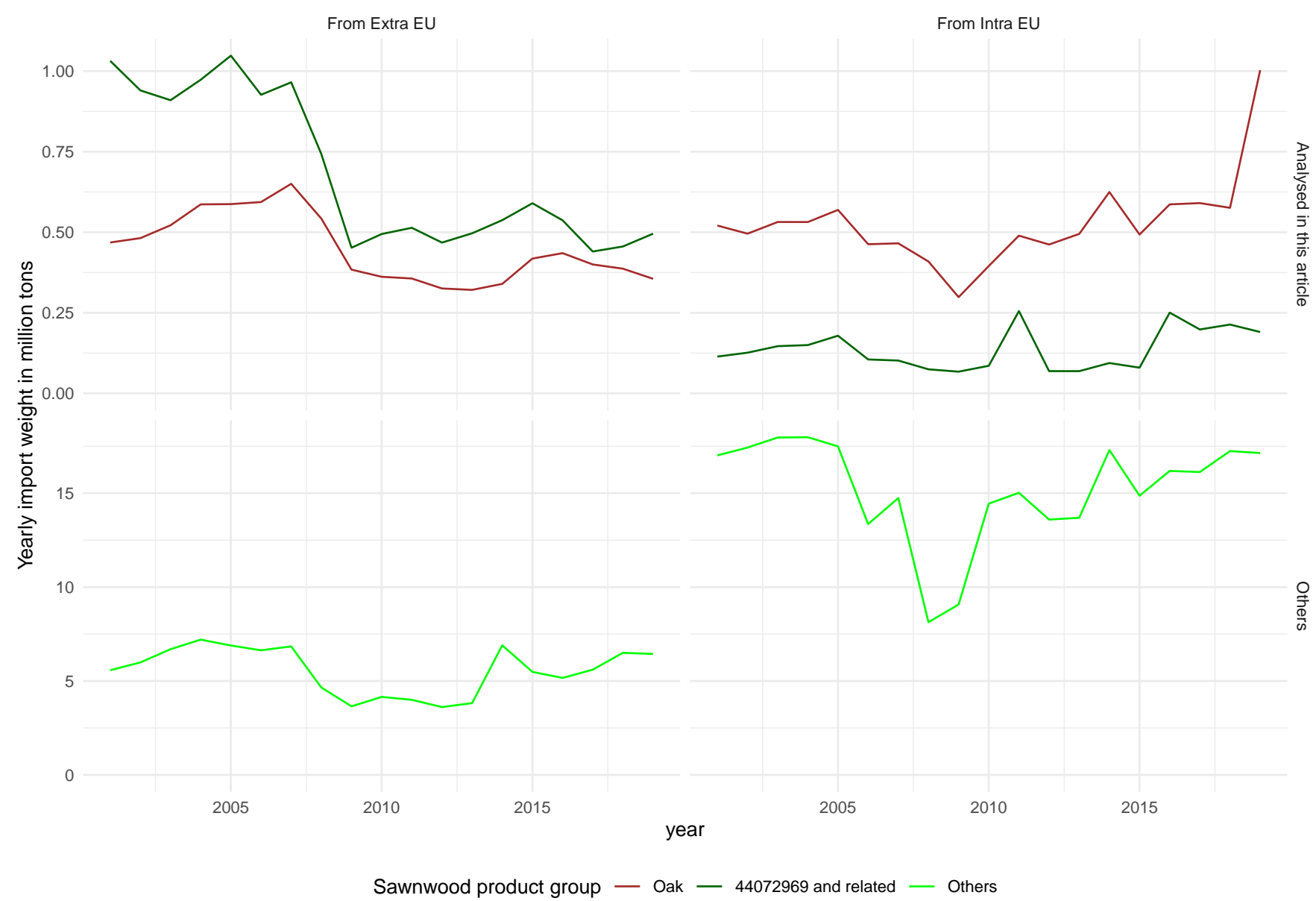

Figure 2. EU sawnwood imports from extra and intra EU partners. The Combined Nomenclature code 44072969 represents tropical hardwood lumber products analyzed in this article. EU = EU27 + UK.

We hypothesize that the implementation of the EUTR resulted in a reduction of supply of tropical timber to EU member states, a result of the discontinuation of the supply of illegal timber and/or the disappearance of some of the legal supply due to the costs of conforming to the requirements of the EUTR. This backward shift of the supply curve would result in a new equilibrium market solution at the higher price, P2, and lower quantity, Q2, in the tropical timber market, ceteris paribus (Figure 3). However, substitution by temperate timbers, such as oak, for tropical timber would in addition to increasing the equilibrium price and quantity in the temperate timber market through increased demand (Figure 3), result in a contraction of the demand (a backwards shift of the demand curve) for the tropical timber being substituted. While this would reinforce the decrease in the equilibrium quantity, it would counter the increase in the equilibrium price in the tropical timber market. The sign of the price movement will depend on the relative strength of the supply and demand shock respectively. The next section describes in detail the data and methods used in the analysis. Then results are reported, followed by the discussion and conclusions. 

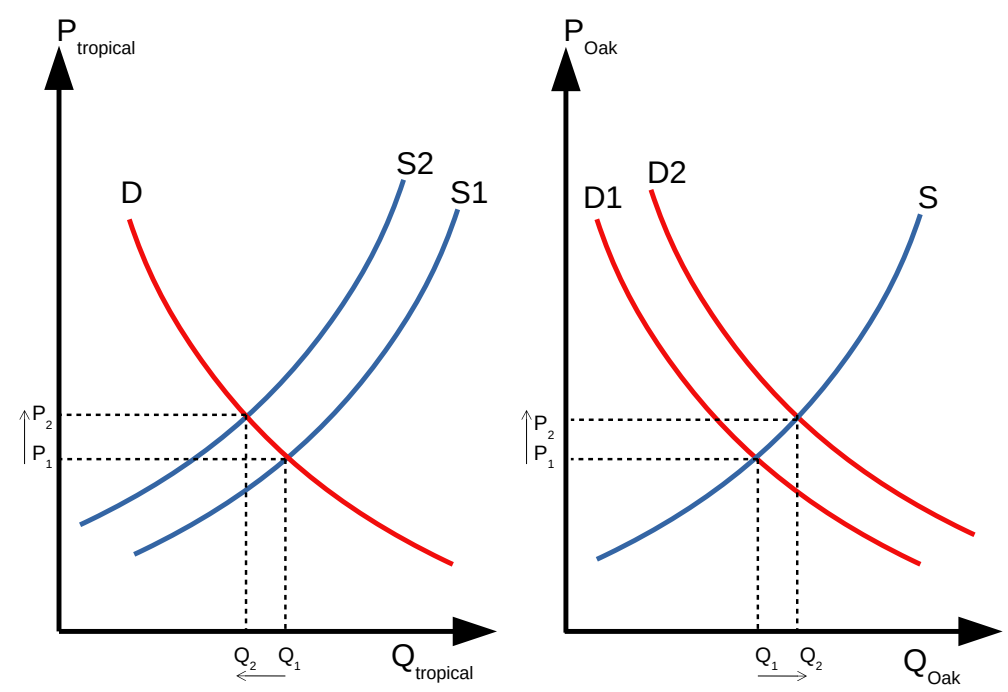

Figure 3. Supply and demand curve for the markets of tropical timber and oak timber.

\section{Materials and Methods}

\subsection{Shock Model}

In an attempt to isolate the effect of the policy change from other economic variations, we analyze the price series of substitute or complementary products. Such products should be affected by economic variations in a similar way throughout the period, thus we look for a difference in how they relate to each other before and after the entry into force of the EUTR. Rather than estimating the effect of the shock directly with a dummy variable in a linear model, we follow the more robust approach of a cointegration intervention model [6]. The analysis starts by splitting the price series before and after the entry into force of the EUTR. We first estimate the relationship between the price of tropical products $P_{r t}$ and the price of temperate products $P_{m t}$ before the shock date (Equation (1)):

$$
\ln P_{r t}=\gamma_{0}+\gamma_{1} \ln P_{m t}+\theta_{t} .
$$

The estimated coefficients are then used to generate pseudo errors $\hat{\mu}_{t}$ after the shock date (Equation (2)). These pseudo errors contain information on how the relationship between the two products change after the shock. Third, the $\hat{\mu}_{t}$ vector is regressed onto a lagged version of itself to estimate $\lambda$, the size of the shock in Equation (3):

$$
\begin{gathered}
\hat{\mu}_{t}=\ln P_{r t}-\hat{\gamma}_{0}-\hat{\gamma}_{1} \ln P_{m t} \\
\hat{\mu}_{t}=\omega_{0}+\omega_{1} \hat{\mu}_{t-1}+\lambda S_{t}+\epsilon_{t} .
\end{gathered}
$$

The $\lambda$ coefficient gives an indication as to how the shock impacted the relationship between tropical and temperate prices. Since we estimate the model with the log of prices, $e^{\lambda}-1$ can be interpreted as a percentage change of prices between a model without the shock and a model with the shock. The same shock model is used to estimate the relationship between the import weight series.

\subsection{Demand Model}

The theoretical background behind the import demand for forest products is explained in [12], based on the general formulation by [13]. The simplest formulation of a macroeconomic demand model relates $Y_{r t}$, the import demand of tropical timber within one country at time $t$ to the price of tropical timber $P_{r t}$ (proxied by the unit price of trade) and national revenue proxied by $G_{t}$, the GDP at time $t$. It is estimated in its logarithm form (Equation (4)). This static model is sometimes estimated in a dynamic form by adding a 
lagged version of the demand $Y_{r(t-1)}$ as an additional regressor, but we only estimate the static version here:

$$
\ln Y_{r t}=\beta_{0}+\beta_{1} \ln P_{r t}+\beta_{3} \ln G_{t} .
$$

Some authors use simultaneous equations to estimate demand and supply in one model [14,15], but such estimations require additional exogenous variables as determinants of the supply side and are therefore generally done on a national level. International demand models on the other hand $[12,16,17]$ are generally estimated with a single equation, independently of the supply. Thus making the assumption that the supply is infinitely elastic. This is a limitation of our model which we could not address at this stage.

To the simple demand model (Equation (4)), we add an additional explanatory variable representing the price of a substitute or complementary product (Equation (5)). The $\beta_{2}$ coefficient can be interpreted as a cross price elasticity of demand:

$$
\ln Y_{r t}=\beta_{0}+\beta_{1} \ln P_{r t}+\beta_{2} \ln P_{m t}+\beta_{3} \ln G_{t}
$$

We estimate the demand model (Equation (5)) from a balanced panel dataset. To capture the unobserved heterogeneity between countries, the estimation is performed with individual country fixed effects. Before performing the estimation, we test for the presence of autocorrelation issues with panel stationarity tests. In the case of a non stationary series, we also estimate the model with differenced variables to remove potential issues with autocorrelation. The problem with results based on differenced variables is that the coefficients cannot be interpreted as elasticities, still, the sign and strength of the coefficient give indications for model comparisons.

\section{Data Preparation}

It is preferable to use a narrow product group so that changing prices represent a market signal and not a change of the product mix among a large basket of products. $\mathrm{CN}$ codes of temperate sawnwood such as oak have remained the same throughout the whole period. Unfortunately, there has been several changes in tropical hardwood lumber product codes throughout the last 20 years and it is not possible to find a stable tropical timber product code at the CN8 level because product descriptions change through time. For example in 2007 product code 444072969 was split into three different codes (44072799, 44072899, and 44072968) described Table A1 in Appendix A. While in 2017, product code 44072960 was merged into 44072995 . These changes are visible Figure A2 in the subplot showing the EU's imports from Africa. To build a long time series of tropical hardwood lumber, we selected products related to 44072969 , which is the sawnwood product with the highest import value over the period. A correspondance table from EUROSTAT describes changes in the Combined Nomenclature of the EU's external trade statistics [18]. Based on that table, we built a procedure that looks forward in time for all products related to 44072969 and then backward for all products that have been related to these products in the past. From that list we excluded the products codes that are not specific to tropical timber. In particular we excluded product codes starting with 440799 . These products are visible in a separate pane as shown in Figure A2. We exclude these product codes because they are not specific to tropical timber and represent mixes of timber of other origins. The procedure leads to an aggregated product category that represents the vast majority of tropical hardwood lumber export in most countries (Figure A1). However there are exceptions such as Malaysia and Indonesia where the chosen product aggregation represents only a fourth of the trade value exported to the EU.

The shock model relates the bilateral import price (and weight) series of tropical timber to the import price (and weight) series of oak. The trade partner chosen for oak lumber imports is the USA, for most EU member states the most important extra-EU supplier. A monthly time series was used to increase the power of the estimation. The estimation techniques require a full time series, but many country pairs do not have a complete series. The detail number of missing data for all country pairs are visible in 
Table A2. Countries with low trade volumes (Table A3) are more likely to have missing data points. We selected country pairs which have zero missing values, in addition we performed linear interpolation for country pairs which had few missing values (less than 20 missing values out of 228 observations). We omitted the other country pairs because they did not have enough observations.

Figure A3 illustrates the evolution of monthly prices, trade values, and weight for some of the largest EU tropical hardwood lumber importers from Cameroon. In Germany and Italy, the import weight and prices of tropical hardwood lumber have the same order of magnitude as the import weight and prices of oak lumber, for this reason the comparison makes most sense in those country pairs. France on the other hand imports very low volumes of oak from the USA, mainly because it is itself a large oak producer. Spain's imports of tropical and oak lumber have strongly decreased after the 2008 financial crisis and never recovered since then. The tropical hardwood lumber import series for Malaysia however show much lower import values compared to oak lumber imports in Germany, Italy, and the UK (Figure A4). Note also the presence of outliers in the Netherlands, as well as the drastic decrease of lumber exports to Belgium. The variable pricew visible in those figures is the ratio of the trade value and weight. This trade unit value is used as a price proxy in the econometric models. It is also possible to compute a price based on the import quantity in cubic metres, but the quantity has more missing data or outliers. That is why we prefer to use the price per units of weight.

The demand model relates aggregate import demand to three variables: The import price of tropical timber, the import price of temperate timber, and GDP. GDP is expressed in constant prices of 2015 based on the chain linked volume method [19]. Monthly GDP data are not available, so we use yearly data. In addition, yearly data smooths seasonal variations which could affect the topical and temperate markets in different ways but the use of yearly data reduces the number of observations from 228 to 19 which negatively impacts the power of the estimation. A further restriction is imposed by the fact that the estimation methods require a balanced panel i.e., observations should be present in all years for all variables and all countries. We removed Cyprus and Malta as they have only 16 years of data and they have the lowest tropical timber import trade value of all countries. We started the series in 2002 to obtain a balanced panel with the largest cross section (N) dimension and the longest time dimension $(\mathrm{T})$ possible. Descriptive statistics of the panel variables used in the demand model are visible in Table A6. Imported weights of tropical hardwood lumber are higher than those of oak in Belgium and France, while they are of a similar order of magnituted in large importing countries such as Germany and Italy (Figure A6), most of the remaining countries import higher oak quantities than tropical hardwood. All import prices follow increasing trends (Figure A7) with tropical prices generally higher than oak prices.

\section{Results and Discussion}

\subsection{Shock Model Estimated on Time Series}

Augmented Dickey Fuller (ADF) tests were performed on the period before the shock data to avoid the potential influence of the shock on the stationarity result. Tables A4 and A5 show that price series are non stationary $(\mathrm{I}(1))$ for most country pairs. Therefore the use of cointegration methods is relevant to avoid spurious regression.

In the fifth column of Table 1 (and Table 2), the cointegration statistics are below the critical value of -3.37 for 28 country pairs (37 country pairs). For those country pairs we reject the null hypothesis that the residuals have unit roots, i.e., the price (weight) series of tropical and oak lumber are cointegrated. Results for the country pair, the Netherlands and Malaysia are not reliable because of the presence of outliers (see Figure A4). 
Table 1. Estimation of a cointegration intervention model between the price series of tropical hardwood lumber and oak lumber. The oak import partner is the U.S. for all countries. Prices are transformed to natural logarithms.

\begin{tabular}{|c|c|c|c|c|c|c|c|c|c|}
\hline Reporter & Partner T & VPA & Ndiffs & Coint Stat & Coint & $e^{\lambda}-1$ & $p$-Value & $R^{2}$ & $\frac{\text { weight }_{T}}{\text { weight }_{K}}$ \\
\hline \multirow{2}{*}{ Belgium } & Cameroon & vpa & 1 & -3.20 & & 0.03 & 0.04 & 0.27 & 18.40 \\
\hline & Brazil & & 1 & -2.81 & & 0.05 & 0.04 & 0.54 & 2.06 \\
\hline Denmark & Brazil & & 1 & -2.35 & & 0.15 & 0.00 & 0.70 & 0.93 \\
\hline \multirow{2}{*}{ France } & Brazil & & 1 & -2.39 & & -0.02 & 0.37 & 0.51 & 6.27 \\
\hline & Cameroon & vpa & 1 & -3.11 & & 0.01 & 0.31 & 0.34 & 9.60 \\
\hline \multirow{2}{*}{ Italy } & Gabon & & 1 & -2.87 & & 0.09 & 0.00 & 0.71 & 0.78 \\
\hline & Côte d'Ivoire & & 1 & -2.96 & & 0.09 & 0.00 & 0.65 & 0.46 \\
\hline \multirow{2}{*}{ Netherlands } & Cameroon & vpa & 1 & -3.06 & & 0.12 & 0.00 & 0.61 & 2.83 \\
\hline & Brazil & & 1 & -2.05 & & 0.34 & 0.00 & 0.11 & 1.76 \\
\hline Portugal & Brazil & & 1 & -2.27 & & 0.09 & 0.00 & 0.66 & 0.56 \\
\hline \multirow{2}{*}{ Spain } & Cameroon & vpa & 1 & -3.10 & & 0.04 & 0.00 & 0.44 & 1.08 \\
\hline & Côte d'Ivoire & & 1 & -2.73 & & 0.21 & 0.00 & 0.42 & 0.14 \\
\hline Utd. Kingdom & Cameroon & vpa & 1 & -3.20 & & 0.15 & 0.00 & 0.75 & 0.51 \\
\hline \multirow{5}{*}{ Belgium } & Côte d'Ivoire & & 0 & -5.52 & coint & -0.18 & 0.00 & 0.27 & 2.14 \\
\hline & Ghana & vpa & 1 & -7.50 & coint & 0.01 & 0.81 & 0.03 & 0.32 \\
\hline & Gabon & & 1 & -7.75 & coint & 0.08 & 0.00 & 0.07 & 6.80 \\
\hline & Malaysia & & 1 & -3.58 & coint & 0.13 & 0.00 & 0.19 & 0.29 \\
\hline & Congo DRC & & 1 & -5.36 & coint & 0.15 & 0.00 & 0.43 & 1.89 \\
\hline \multirow{5}{*}{ France } & Malaysia & & 1 & -4.80 & coint & 0.01 & 0.74 & 0.25 & 1.73 \\
\hline & Côte d'Ivoire & & 1 & -3.65 & coint & 0.03 & 0.34 & 0.13 & 0.79 \\
\hline & Ghana & vpa & 1 & -3.49 & coint & 0.04 & 0.14 & 0.02 & 0.97 \\
\hline & Gabon & & 1 & -6.18 & coint & 0.05 & 0.01 & 0.08 & 1.31 \\
\hline & Congo & vpa & 1 & -5.01 & coint & 0.06 & 0.00 & 0.16 & 2.67 \\
\hline \multirow{3}{*}{ Germany } & Ghana & vpa & 1 & -5.18 & coint & 0.12 & 0.00 & 0.77 & 0.34 \\
\hline & Cameroon & vpa & 1 & -5.07 & coint & 0.27 & 0.00 & 0.59 & 0.34 \\
\hline & Malaysia & & 1 & -4.40 & coint & 0.83 & 0.00 & 0.25 & 0.06 \\
\hline \multirow{2}{*}{ Greece } & Côte d'Ivoire & & 1 & -5.84 & coint & 0.08 & 0.00 & 0.11 & 0.74 \\
\hline & Cameroon & vpa & 1 & -6.44 & coint & 0.10 & 0.00 & 0.10 & 0.65 \\
\hline Ireland & Cameroon & vpa & 1 & -7.87 & coint & 0.22 & 0.00 & 0.23 & 2.72 \\
\hline \multirow{4}{*}{ Italy } & Congo & vpa & 0 & -5.44 & coint & 0.12 & 0.00 & 0.14 & 0.12 \\
\hline & Cameroon & vpa & 1 & -4.77 & coint & 0.13 & 0.00 & 0.69 & 1.24 \\
\hline & Ghana & vpa & 1 & -4.95 & coint & 0.16 & 0.00 & 0.32 & 0.06 \\
\hline & Malaysia & & 1 & -4.55 & coint & 0.24 & 0.00 & 0.08 & 0.10 \\
\hline \multirow{2}{*}{ Netherlands } & Malaysia & & 1 & -4.79 & coint & -0.30 & 0.00 & 0.43 & 5.02 \\
\hline & Côte d'Ivoire & & 1 & -6.17 & coint & 0.07 & 0.20 & 0.02 & 0.77 \\
\hline \multirow{2}{*}{ Portugal } & Cameroon & vpa & 1 & -3.66 & coint & 0.04 & 0.03 & 0.33 & 0.46 \\
\hline & Gabon & & 1 & -7.23 & coint & 0.10 & 0.00 & 0.11 & 0.22 \\
\hline Spain & Brazil & & 1 & -3.74 & coint & -0.02 & 0.53 & 0.30 & 0.26 \\
\hline \multirow{3}{*}{ Utd. Kingdom } & Malaysia & & 1 & -3.80 & coint & 0.12 & 0.00 & 0.39 & 0.11 \\
\hline & Côte d'Ivoire & & 1 & -4.34 & coint & 0.15 & 0.00 & 0.66 & 0.13 \\
\hline & Ghana & vpa & 1 & -6.08 & coint & 0.16 & 0.00 & 0.16 & 0.05 \\
\hline
\end{tabular}


Table 2. Estimation of a cointegration intervention model between the import weight series of tropical hardwood lumber and oak lumber. Variables are transformed to natural logarithms.

\begin{tabular}{|c|c|c|c|c|c|c|c|c|c|}
\hline Reporter & Partner T & VPA & Ndiffs & Coint Stat & Coint & $e^{\lambda}-1$ & $p$-Value & $R^{2}$ & $\frac{\text { weight }_{T}}{\text { weight }_{K}}$ \\
\hline France & Brazil & & 1 & -3.24 & & -0.24 & 0.00 & 0.61 & 6.27 \\
\hline \multirow{3}{*}{ Italy } & Ghana & vpa & 1 & -2.18 & & -0.42 & 0.00 & 0.57 & 0.06 \\
\hline & Côte d'Ivoire & & 1 & -1.74 & & -0.17 & 0.01 & 0.77 & 0.46 \\
\hline & Cameroon & vpa & 1 & -2.33 & & -0.08 & 0.13 & 0.53 & 1.24 \\
\hline \multirow{7}{*}{ Belgium } & Ghana & vpa & 0 & -5.12 & coint & -0.22 & 0.01 & 0.07 & 0.32 \\
\hline & Congo DRC & & 1 & -5.75 & coint & -0.12 & 0.29 & 0.13 & 1.89 \\
\hline & Malaysia & & 1 & -5.54 & coint & 0.06 & 0.64 & 0.07 & 0.29 \\
\hline & Brazil & & 0 & -5.51 & coint & 0.17 & 0.03 & 0.21 & 2.06 \\
\hline & Cameroon & vpa & 1 & -4.33 & coint & 0.23 & 0.00 & 0.35 & 18.40 \\
\hline & Côte d'Ivoire & & 0 & -5.53 & coint & 0.80 & 0.00 & 0.23 & 2.14 \\
\hline & Gabon & & 1 & -5.91 & coint & 1.00 & 0.00 & 0.22 & 6.80 \\
\hline Denmark & Brazil & & 0 & -7.22 & coint & 0.15 & 0.18 & 0.07 & 0.93 \\
\hline \multirow{6}{*}{ France } & Côte d'Ivoire & & 1 & -5.52 & coint & -0.60 & 0.00 & 0.29 & 0.79 \\
\hline & Ghana & vpa & 1 & -3.95 & coint & -0.59 & 0.00 & 0.25 & 0.97 \\
\hline & Malaysia & & 0 & -7.72 & coint & -0.40 & 0.00 & 0.17 & 1.73 \\
\hline & Cameroon & vpa & 0 & -6.11 & coint & -0.16 & 0.00 & 0.06 & 9.60 \\
\hline & Gabon & & 1 & -5.64 & coint & -0.12 & 0.16 & 0.02 & 1.31 \\
\hline & Congo & vpa & 0 & -5.64 & coint & 0.33 & 0.00 & 0.09 & 2.67 \\
\hline \multirow{3}{*}{ Germany } & Malaysia & & 1 & -4.96 & coint & -0.68 & 0.00 & 0.29 & 0.06 \\
\hline & Cameroon & vpa & 1 & -7.31 & coint & -0.54 & 0.00 & 0.31 & 0.34 \\
\hline & Ghana & vpa & 1 & -4.42 & coint & -0.38 & 0.00 & 0.57 & 0.34 \\
\hline \multirow{2}{*}{ Greece } & Côte d'Ivoire & & 1 & -7.50 & coint & 0.14 & 0.17 & 0.01 & 0.74 \\
\hline & Cameroon & vpa & 0 & -7.28 & coint & 0.71 & 0.00 & 0.09 & 0.65 \\
\hline Ireland & Cameroon & vpa & 1 & -5.32 & coint & 0.00 & 0.99 & 0.09 & 2.72 \\
\hline \multirow{3}{*}{ Italy } & Malaysia & & 1 & -3.78 & coint & -0.57 & 0.00 & 0.40 & 0.10 \\
\hline & Congo & vpa & 0 & -7.62 & coint & -0.20 & 0.07 & 0.08 & 0.12 \\
\hline & Gabon & & 1 & -4.20 & coint & -0.01 & 0.93 & 0.18 & 0.78 \\
\hline \multirow{4}{*}{ Netherlands } & Côte d'Ivoire & & 0 & -4.63 & coint & -0.54 & 0.00 & 0.23 & 0.77 \\
\hline & Cameroon & vpa & 1 & -4.85 & coint & 0.14 & 0.20 & 0.12 & 2.83 \\
\hline & Brazil & & 1 & -4.45 & coint & 0.41 & 0.07 & 0.12 & 1.76 \\
\hline & Malaysia & & 1 & -5.45 & coint & 0.60 & 0.00 & 0.37 & 5.02 \\
\hline \multirow{3}{*}{ Portugal } & Brazil & & 1 & -5.13 & coint & -0.36 & 0.00 & 0.28 & 0.56 \\
\hline & Cameroon & vpa & 0 & -8.06 & coint & -0.35 & 0.00 & 0.13 & 0.46 \\
\hline & Gabon & & 0 & -7.20 & coint & 0.46 & 0.00 & 0.07 & 0.22 \\
\hline \multirow{3}{*}{ Spain } & Côte d'Ivoire & & 1 & -4.82 & coint & -0.34 & 0.00 & 0.33 & 0.14 \\
\hline & Brazil & & 1 & -5.79 & coint & 0.00 & 0.99 & 0.03 & 0.26 \\
\hline & Cameroon & vpa & 1 & -6.67 & coint & 0.12 & 0.06 & 0.06 & 1.08 \\
\hline \multirow{4}{*}{ Utd. Kingdom } & Ghana & vpa & 1 & -4.81 & coint & -0.50 & 0.00 & 0.32 & 0.05 \\
\hline & Malaysia & & 1 & -4.18 & coint & -0.42 & 0.00 & 0.34 & 0.11 \\
\hline & Côte d'Ivoire & & 0 & -5.77 & coint & -0.39 & 0.00 & 0.40 & 0.13 \\
\hline & Cameroon & vpa & 0 & -8.05 & coint & -0.08 & 0.20 & 0.01 & 0.51 \\
\hline
\end{tabular}

For the country pairs Belgium-Ghana, France-Malaysia, France-Côte d'Ivoire, France-Ghana, Netherlands-Côte d'Ivoire, and Spain-Brazil, $\lambda$ is not significantly different from zero, meaning that there is no significant change in the price relationship after the EUTR start date. In 22 of the cointegrated price series, the lambda coefficients are significant, and of these all but two, Belgium-Côte d'Ivoire and Netherlands-Malaysia, 
are positive (Table 1). This implies, with these two exceptions, increasing prices for tropical hardwood lumber following the introduction of the EUTR, ranging from $4 \%$ (PortugalCameroon) to $83 \%$ (Germany-Malaysia).

The results of a shock model based on a time series of import weights (Table 2) show more cases where $\lambda$ is not significantly different from zero (for the country pairs Belgium-Congo DRC, Belgium-Malaysia, Denmark-Brazil, France-Gabon, Greec e-Côte d'Ivoire, Ireland-Cameroon, Italy-Congo, Italy-Gabon, Netherlands-Brazil, Netherlands_Cameroon, Spain-Brazil, Spain-Cameroon, and Utd. Kingdom-Cameroon). Eight country pairs - of which four Belgian import partners, all important in terms of trade volumes-have significant and positive lambdas, indicating increasing imports of tropical hardwood lumber relative to temperate lumber imports after the shock. The remaining 16 country pairs have significant and negative lambdas, implying decreasing imports of tropical lumber relative to oak lumber imports after the introduction of the EUTR. In percentage terms, German imports of tropical hardwood lumber from Malaysia and French imports from Côte d'Ivoire show notable reductions. In quantity terms, however, there are many other tropical hardwood lumber import flows that show stronger reductions after the shock, such as, e.g., German imports from Cameroon, French imports from Cameroon and Ghana, and Portuguese imports from Brazil and Cameroon. Figure A5 illustrates how a negative lambda captures some of the decrease in residuals after the EUTR start date, leading to a change of model from the dotted blue curve to the red curve (particularly visible in the quadrants of Germany for example). VPA member countries (third column in Tables 1 and 2) do not exhibit any clear pattern that would distinguish them from non-VPA countries.

Hence, our results from the shock model show considerable consistency with those of Prestemon [6], as there are general increases in the prices and decreases in the import quantities of tropical timber relative to temperate timber after the implementation of a policy instrument aimed at curbing the trade in illegal timber. This pattern is consistent with a reduction of the supply of tropical timber to these EU member states. There are however notable exceptions of coincedental decreasing prices and increases in import quantities of tropical sawnwod, which would be consistent with an increase in the supply of tropical timber in these cases.

\subsection{Demand Model Estimated on Panel Data}

Before performing the estimation of the demand models, we tested the stationarity of the individual time series and of the panel as a whole. Augmented Dickey-Fuller tests fail to reject the null hypothesis of stationarity for most time series in most countries (Table A7). Panel stationarity tests reported in Table A8 are less conclusive. The Maddala and Wu and Levin-Lin-Chu tests both assume a null hypothesis that some of the series in the panel have a unit root. Both tests reject the null hypothesis for the explained variable, i.e., import demand can be considered stationary. The Maddala and $\mathrm{Wu}$ test rejects the null hypothesis for both price variables but the Levin-Lin-Chu weakly fails to reject the null. The Hadri test rejects the null hypothesis of stationarity for all variables. It should be noted that stationarity tests can be biased in the presence of structural breaks. In the absence of a clear answer in favor of stationarity, we have estimated the model with variables in level and with differenced variables. Estimated coefficients (Table 3) are reported with clustered standard errors to adjust for the fact that in a panel fixed effect model, the composite error term is correlated over time [20].

Table 3 shows, first of all, that the own price elasticity of import demand is negative, as expected by the theory. It is however only significant, and elastic, which is considerably higher than the elasticity of -0.7 estimated by Turner and Buongiorno [12], over the whole period and the first time period, becoming insignificant for the period following the EUTR implementation. Second, the cross-price elasticity with respect to oak lumber is never significant, and the same applies to the income elasticity of demand. In general, the 
demand models fit poorly with the explanatory variables, a consequence of the important inter-country variability.

Table 3. Panel data fixed effects estimation of a tropical hardwood lumber demand model.

\begin{tabular}{|c|c|c|c|c|c|c|}
\hline & \multicolumn{6}{|c|}{ Dependent Variable: } \\
\hline & \multicolumn{3}{|c|}{ Lweight_Trop } & \multicolumn{3}{|c|}{ Diff(Lweight_Trop) } \\
\hline & $\begin{array}{l}2002-2019 \\
\text { (1) }\end{array}$ & $\begin{array}{c}2002-2013 \\
\text { (2) }\end{array}$ & $\begin{array}{c}\text { 2014-2019 } \\
\text { (3) }\end{array}$ & $\begin{array}{c}2003-2019 \\
\text { (4) }\end{array}$ & $\begin{array}{c}2003-2013 \\
\text { (5) }\end{array}$ & $\begin{array}{c}2015-2019 \\
\text { (6) }\end{array}$ \\
\hline lpricew_trop & $\begin{array}{c}-1.239 * * * \\
(0.313)\end{array}$ & $\begin{array}{c}-1.373^{* * *} \\
(0.392)\end{array}$ & $\begin{array}{l}-0.278 \\
(0.226)\end{array}$ & & & \\
\hline lpricew_oak & $\begin{array}{c}0.041 \\
(0.187)\end{array}$ & $\begin{array}{c}0.328 \\
(0.213)\end{array}$ & $\begin{array}{l}-0.081 \\
(0.191)\end{array}$ & & & \\
\hline lgdp_const_eur & $\begin{array}{c}0.029 \\
(0.494)\end{array}$ & $\begin{array}{c}0.820 \\
(0.532)\end{array}$ & $\begin{array}{l}-0.162 \\
(0.990)\end{array}$ & & & \\
\hline diff(lpricew_trop) & & & & $\begin{array}{c}-0.830 * * * \\
(0.107)\end{array}$ & $\begin{array}{c}-1.004^{* * *} \\
(0.140)\end{array}$ & $\begin{array}{c}-0.695^{* * *} \\
(0.143)\end{array}$ \\
\hline diff(lpricew_oak) & & & & $\begin{array}{l}-0.091 \\
(0.086)\end{array}$ & $\begin{array}{c}0.004 \\
(0.171)\end{array}$ & $\begin{array}{l}-0.219 \\
(0.201)\end{array}$ \\
\hline diff(lgdp_const_eur) & & & & $\begin{array}{c}5.240^{* * *} \\
(0.739)\end{array}$ & $\begin{array}{c}5.785^{* * *} \\
(0.759)\end{array}$ & $\begin{array}{l}-0.300 \\
(1.404)\end{array}$ \\
\hline Observations & 432 & 288 & 144 & 408 & 264 & 120 \\
\hline $\mathrm{R}^{2}$ & 0.270 & 0.233 & 0.021 & 0.287 & 0.383 & 0.130 \\
\hline
\end{tabular}

Note: ${ }^{* *} p<0.01$.

We also estimated an oak import demand model (Table 4). The own price elasticity is negative, again in accordance with theory, and stable through time. A price elasticity equal to -0.7 is similar to the value obtained in the fixed effect estimation of a static import demand model by Turner and Buongiorno [12]. Clearly the own price elasticity of oak import demand does not change over time. Furthermore, the cross-price elasticity with respect to tropical hardwood lumber is not significant over the whole time period and before the EUTR start date. It is significant and positive when estimated over the 2014-2019 period, indicating that tropical and oak lumber are substitutes, but it is not significant when estimated on differenced variables.

Table 4. Panel data fixed effects estimation of oak lumber demand.

\begin{tabular}{|c|c|c|c|c|c|c|}
\hline & \multicolumn{6}{|c|}{ Dependent Variable: } \\
\hline & \multicolumn{3}{|c|}{ Lweight_Oak } & \multicolumn{3}{|c|}{ Diff(Lweight_Oak) } \\
\hline & $\begin{array}{l}2002-2019 \\
\text { (1) }\end{array}$ & $\begin{array}{l}2002-2013 \\
\text { (2) }\end{array}$ & $\begin{array}{c}\text { 2014-2019 } \\
\text { (3) }\end{array}$ & $\begin{array}{c}2003-2019 \\
\text { (4) }\end{array}$ & $\begin{array}{c}2003-2013 \\
\text { (5) }\end{array}$ & $\begin{array}{c}2015-2019 \\
\text { (6) }\end{array}$ \\
\hline lpricew_trop & $\begin{array}{l}-0.186 \\
(0.248)\end{array}$ & $\begin{array}{l}-0.323 \\
(0.251)\end{array}$ & $\begin{array}{c}0.304^{* *} \\
(0.150)\end{array}$ & & & \\
\hline lpricew_oak & $\begin{array}{c}-0.727^{* * *} \\
(0.102)\end{array}$ & $\begin{array}{c}-0.753^{* * * *} \\
(0.221)\end{array}$ & $\begin{array}{c}-0.713^{* * *} \\
(0.105)\end{array}$ & & & \\
\hline lgdp_const_eur & $\begin{array}{c}2.302^{* * *} \\
(0.679)\end{array}$ & $\begin{array}{c}2.745^{* * *} \\
(0.615)\end{array}$ & $\begin{array}{l}1.603^{*} \\
(0.897)\end{array}$ & & & \\
\hline diff(lpricew_trop) & & & & $\begin{array}{c}0.033 \\
(0.039)\end{array}$ & $\begin{array}{l}-0.038 \\
(0.084)\end{array}$ & $\begin{array}{c}0.043 \\
(0.068)\end{array}$ \\
\hline diff(lpricew_oak) & & & & $\begin{array}{c}-0.898^{* * *} \\
(0.064)\end{array}$ & $\begin{array}{c}-0.820 * * * \\
(0.123)\end{array}$ & $\begin{array}{c}-0.920^{* * *} \\
(0.038)\end{array}$ \\
\hline diff(lgdp_const_eur) & & & & $\begin{array}{c}4.095^{* * * *} \\
(0.686)\end{array}$ & $\begin{array}{c}4.599 * * * \\
(0.690)\end{array}$ & $\begin{array}{l}-0.251 \\
(0.637)\end{array}$ \\
\hline Observations & 432 & 288 & 144 & 408 & 264 & 120 \\
\hline $\mathrm{R}^{2}$ & 0.271 & 0.321 & 0.364 & 0.527 & 0.504 & 0.642 \\
\hline
\end{tabular}


The assessment as to whether tropical and oak lumber are substitute or complementary products is more plausible when their import volumes are of the same order of magnitude. This is true for many countries, but this is not the case in France which has a large domestic oak production and as a consequence imports small amounts of oak at higher prices (Figure A3). An indication of the ratio of tropical to oak lumber import is given in the shock models results (Tables 1 and 2). In general, we observe that the import demand for oak lumber behaves similarly to a more general sawnwood demand import model [12].

\section{Summary and Conclusions}

The EU Timber Regulation (EUTR) is a key element of the Forest Law Enforcement, Governance and Trade (FLEGT) Action Plan aimed at curbing illegal logging and its associated trade. Due to the rather short time that the EUTR has been in force, there are yet no studies that have performed systematic, comprehensive statistical analysis as to impacts on international trade in timber products. This study aims to help fill this research gap by assessing whether the patterns of EU imports of hardwood timber products have changed as a result of the coming into force of the EUTR. In addition to the analysis itself, to the best of our knowledge the first attempt at a comprehensive statistical analysis of the effects of the EUTR, a major contribution of the paper is the procedure for tackling the issue of the frequent changes in tropical hardwood lumber product codes, in order to build as long and homogenous a time series as possible.

The cointegration intervention, or shock, models analysis, indicate-for most of the bilateral trade flows (EU member states imports) where we observe cointegration and a significant shock variable - that increasing import prices and decreasing import quantities of tropical hardwood lumber relative oak lumber. This is consistent with a predominant reduction of the supply of tropical timber in these cases. There are however notable exceptions from this pattern, in terms of coincedental decreases of prices and increases in import quantities of tropical sawnwod, which would instead be consistent with an increase in the supply of tropical timber in these cases. In addition, the model does not show any clear difference in results between VPA and non-VPA countries.

The results of the import demand models do not give a clear indication as to whether oak lumber is a complementary or substitute product to/for tropical hardwood sawnwood, and they do not give an unanimous picture as to any potential structural changes in demand elasticities after the entry into effect of the EUTR. It should be noted that price variables used in the demand model consider that the supply is infinitely elastic [12], but this assumption is a tad unrealistic, since the EUTR could be seen to introduce supply constraints, in the sense of costs of complying with the requirements of the legislation. An extension of this work could analyze the supply side of the market.

We estimate models before and after the EUTR start date respectively. However, changes in the market due to EUTR legislation are likely to happen gradually rather than discretely. Hence, market operators may have anticipated the introduction of the EUTR, as suggested by some studies [21]. Furthermore, the first legal cases of enforcement occurred several years after the EUTR entered into force. A growing body of legal proceedings on EUTR enforcement is likely to increase the dissuasive effect of the legislation, and to increase compliance of due diligence. These processes are ongoing, and their effects will be measurable over the next decade. It is therefore likely that the structural changes in demand and supply functions are not abrupt, but gradual, following a smooth transition from one model to a new post-EUTR model.

Even assuming that we have captured the most pertinent effects of the EUTR on EU imports of tropical hardwood sawnwood, we are not in a position to assess whether the regulation has been successful in curbing illegal logging and its associated trade. Thus, reduced supply of tropical timber to EU member states might indicate that exporters have seized exporting illegal timber to these destinations. However, this would not necessarily mean that illegal logging in the exporting nation has decreased, as the illegal timber could have been diverted to other less regulated markets, either abroad and/or domestic. 
Further, it is important that the EUTR does not deter the export of legal timber products from developing countries to the EU. Addressing these issues also calls for a study of the supply of tropical timber products, in particular trade diversion, to complement the current analysis.

Author Contributions: Conceptualization, P.R. and R.J.; methodology, P.R. and R.J.; software, P.R.; validation, P.R. and R.J.; formal analysis, P.R.; data curation, P.R.; writing-original draft preparation, P.R. and R.J.; writing-review and editing, P.R. and R.J.; visualization, P.R. Both authors have read and agreed to the published version of the manuscript.

Funding: This research received no external funding.

Institutional Review Board Statement: Not applicable.

Informed Consent Statement: Not applicable.

Data Availability Statement: Data and R scripts supporting the reported results can be found at https:/ / doi.org/10.6084/m9.figshare.14519562, accessed on 28 April 2021, or https:/ / gitlab.com/ paulrougieux/eutr_trade_impact_sustainability/, accessed on 28 April 2021.

Acknowledgments: The work described in this paper has (though not constituting its official output) been carried out in the context of the JRC Biomass assessment study https://ec.europa.eu/ knowledge4policy/projects-activities/jrc-biomass-study_en, accessed on 28 April 2021.

Conflicts of Interest: The authors declare no conflict of interest. The opinions expressed herein are those of the authors and do not necessarily reflect the views of the European Commission. The scientific output does not imply a policy position of the European Commission.

\section{Abbreviations}

The following abbreviations are used in this manuscript:
ADF Augmented Dickey Fuller
$\mathrm{CN} \quad$ Combined Nomenclature
FLEGT Forest Law Enforcement, Governance and Trade
EUTR European Union Timber Regulation 
Appendix A. Extra Tables and Graphs
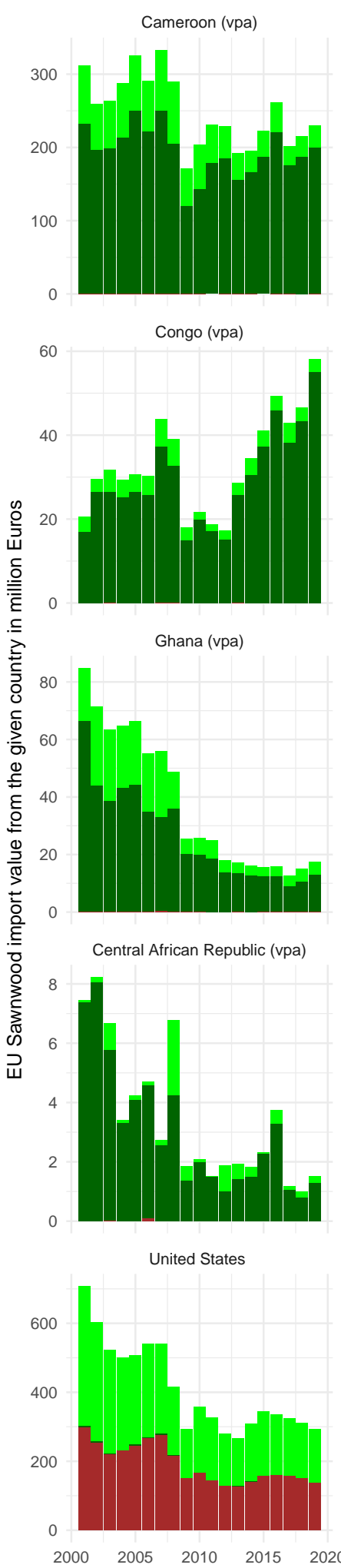

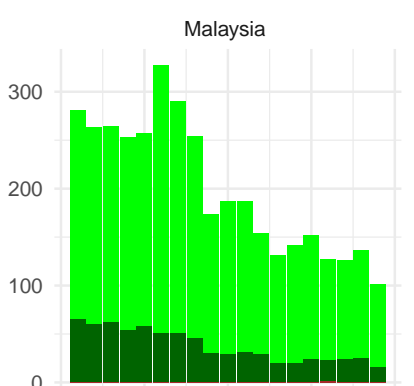

Myanmar

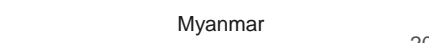

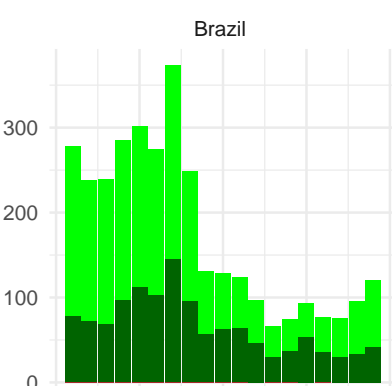

Côte d'Ivoire

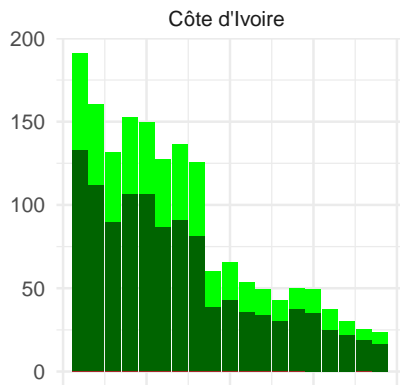

Viet Nam (vpa)

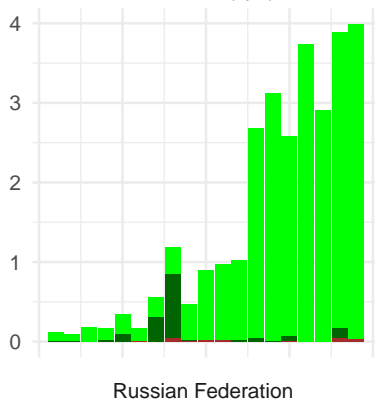

Liberia (vpa)

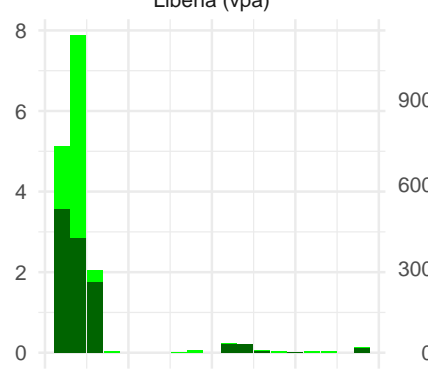

Ukraine

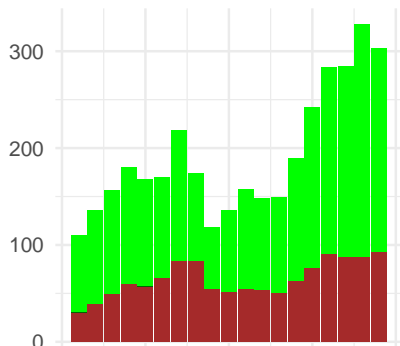

0
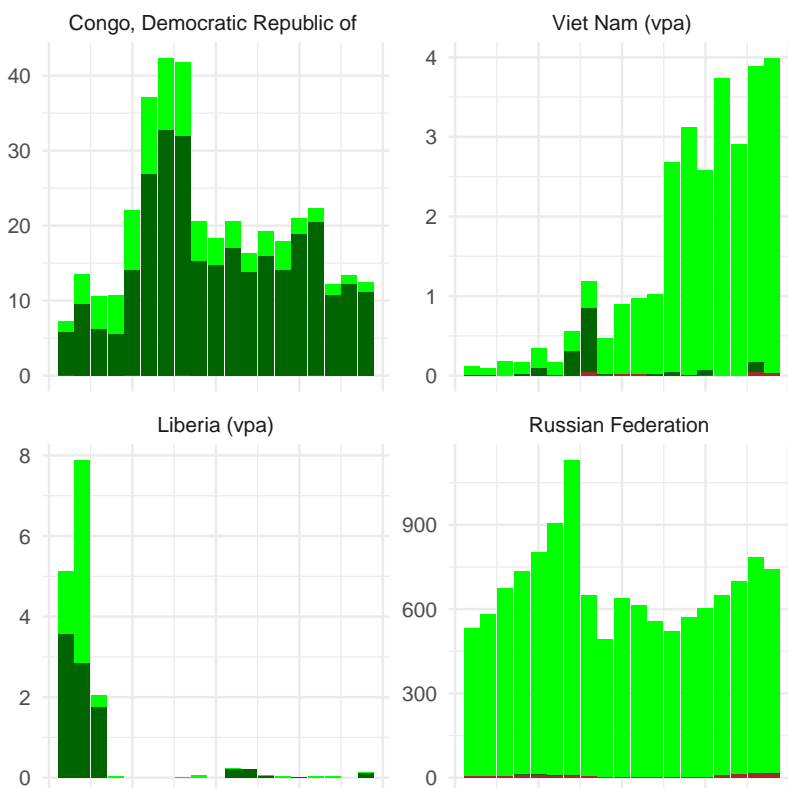

Canada
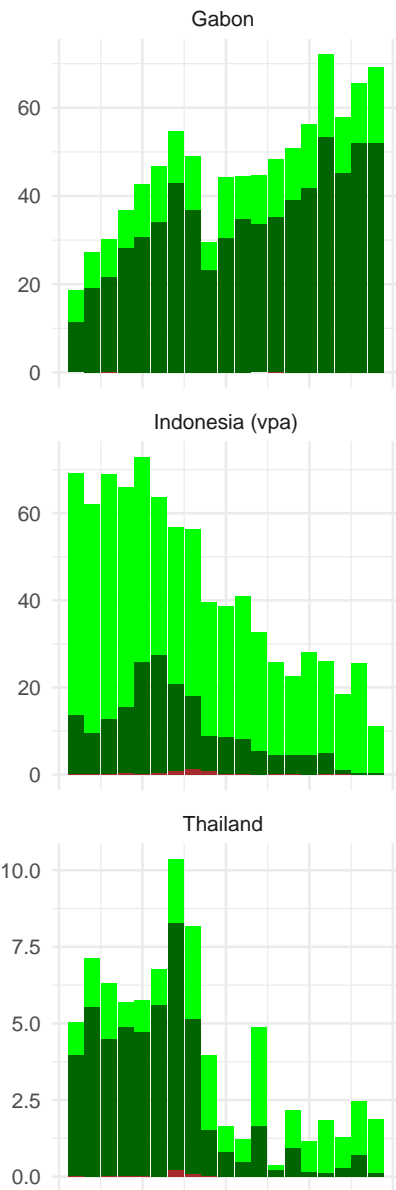

Belarus
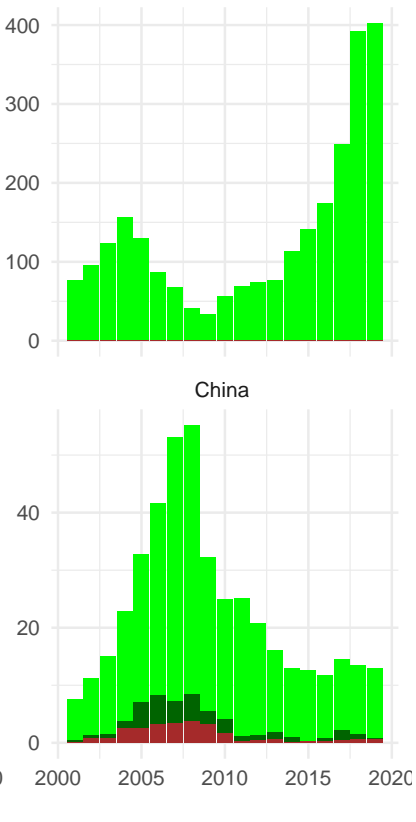

Sawnwood product group _ Oak 44072969 and related $ـ$ Others

Figure A1. EU sawnwood imports from tropical countries and major temperate partner countries. EU = EU27 + UK. 


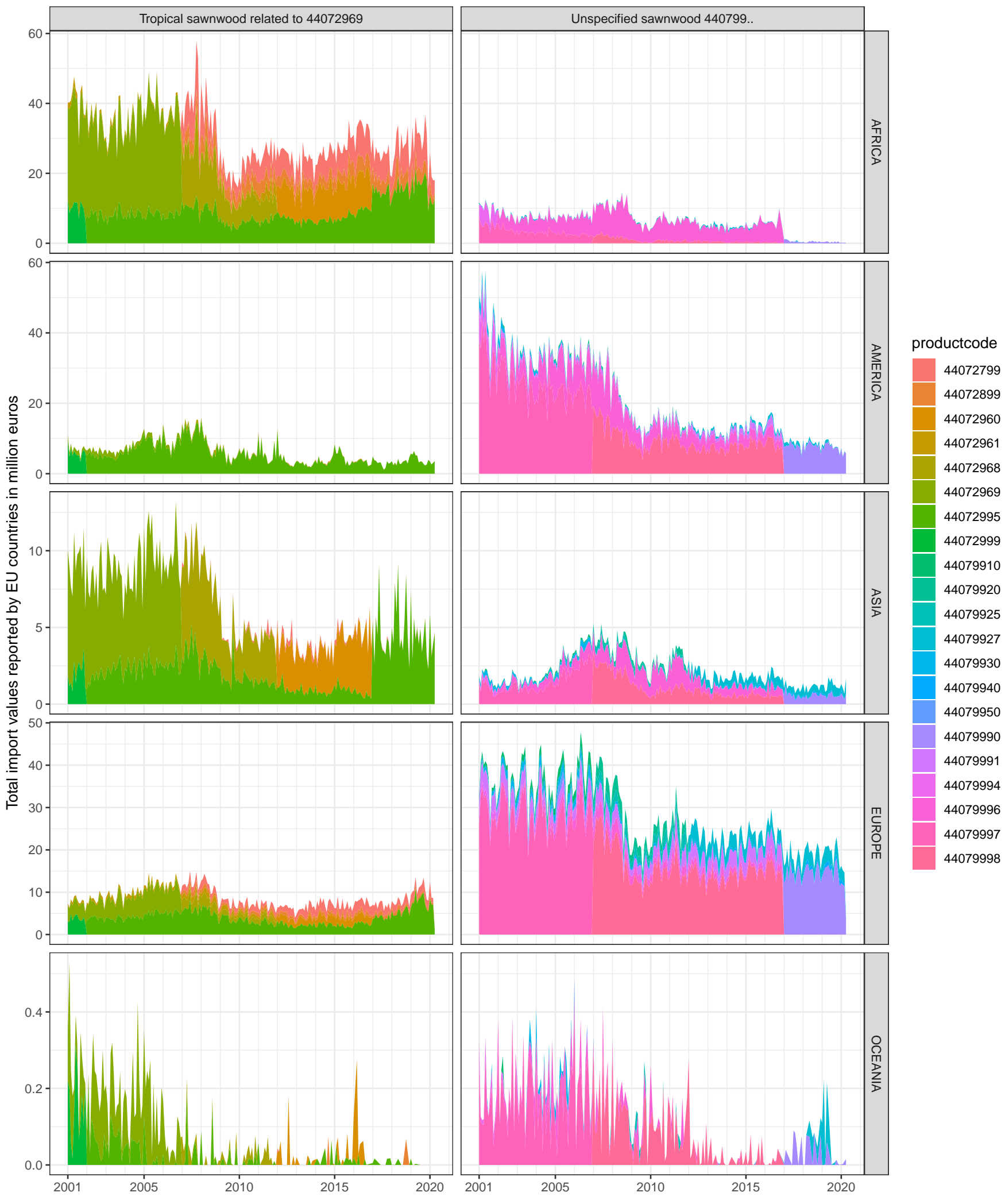

Figure A2. Changes in EU tropical sawnwood imports for product codes related to 44072969. Other sawnwood of unknown classifiation under 440799 are plotted in the second column. 
Table A1. Description of sawnwood product codes related to 44072969.

\begin{tabular}{|c|c|}
\hline Code & Description \\
\hline 44072180 & $\begin{array}{l}\text { Meranti bakau, white seraya, yellow meranti, alen, keruing, ramin, kapur, teak, jongkong, merbau, } \\
\text { jelutong and kempas, sawn or cut lengthwise, sliced or peeled, of a thickness of }>6 \mathrm{~mm} \text { (excl. such } \\
\text { products planed, sanded, or finger-jointed) }\end{array}$ \\
\hline 44072190 & $\begin{array}{l}\text { Dark red meranti, light red meranti, meranti bakau, white lauan, white meranti, white seraya, yellow } \\
\text { meranti, alen, keruing, ramin, kapur, teak, jongkong, merbau, jelutong, and kempas, sawn or cut } \\
\text { lengthwise, sliced or barked, with a thickness of }>6 \mathrm{~mm} \text { (excl. planed, sanded, or finger-jointed) }\end{array}$ \\
\hline 44072260 & $\begin{array}{l}\text { Azobé, sawn or cut lengthwise, sliced or peeled, of a thickness of }>6 \mathrm{~mm} \text { (excl. such products planed, } \\
\text { sanded, or finger-jointed) }\end{array}$ \\
\hline 44072280 & $\begin{array}{l}\text { Okoumé, obeche, sapelli, sipo, acajou d'Afrique, makoré, iroko, tiama, mansonia, ilomba, dibétou, and } \\
\text { limba woods, sawn or cut lengthwise, sliced or peeled, of a thickness of }>6 \mathrm{~mm} \text { (excl. such products } \\
\text { planed, sanded, or finger-jointed) }\end{array}$ \\
\hline 44072290 & $\begin{array}{l}\text { Okoume, obeche, sapele, utile, african mahogany, makore, iroko, tiama, mansonia, ilomba, dibetou, limba, } \\
\text { and azobe, sawn or cut lengthwise, sliced or barked, with a thickness of }>6 \mathrm{~mm} \text { (excl. planed, sanded, } \\
\text { or finger-jointed) }\end{array}$ \\
\hline 44072799 & $\begin{array}{l}\text { Sapelli, sawn, or chipped lengthwise, sliced or peeled, of a thickness of }>6 \mathrm{~mm} \text { (excl. planed, sanded, } \\
\text { or end-jointed) }\end{array}$ \\
\hline 44072899 & $\begin{array}{l}\text { Iroko, sawn, or chipped lengthwise, sliced or peeled, of a thickness of }>6 \mathrm{~mm} \text { (excl. planed, sanded, } \\
\text { or end-jointed) }\end{array}$ \\
\hline 44072960 & $\begin{array}{l}\text { Keruing, ramin, kapur, teak, jongkong, merbau, jelutong, kempas, okoumé, obeche, sipo, acajou } \\
\text { d'Afrique, makoré, tiama, mansonia, ilomba, dibétou, limba, azobé, palissandre de Rio, palissandre de } \\
\text { Para, and palissandre de rose, sawn or chipped lengthwise, sliced or peeled, of a thickness of }>6 \mathrm{~mm} \text { (excl. } \\
\text { such products planed, sanded, or end-jointed) }\end{array}$ \\
\hline 44072961 & $\begin{array}{l}\text { Azobé, sawn or chipped lengthwise, sliced or peeled, of a thickness of }>6 \mathrm{~mm} \text { (excl. such products planed, } \\
\text { sanded, or end-jointed) }\end{array}$ \\
\hline 44072968 & $\begin{array}{l}\text { Keruing, ramin, kapur, teak, jongkong, merbau, jelutong, kempas, okoumé, obeche, sipo, acajou } \\
\text { d'Afrique, makoré, tiama, mansonia, ilomba, dibétou, limba, palissandre de Rio, palissandre de Para, and } \\
\text { palissandre de rose, sawn or chipped lengthwise, sliced or peeled, of a thickness of }>6 \mathrm{~mm} \text { (excl. such } \\
\text { products planed, sanded, or end-jointed) }\end{array}$ \\
\hline 44072969 & $\begin{array}{l}\text { Keruing, ramin, kapur, teak, jongkong, merbau, jelutong, kempas, okoumé, obeche, sapelli, sipo, acajou } \\
\text { d'Afrique, makoré, iroko, tiama, mansonia, ilomba, dibétou, limba, palissandre de Rio, palissandre de } \\
\text { Para, and palissandre de rose, sawn or chipped lengthwise, sliced or peeled, of a thickness of }>6 \mathrm{~mm} \text { (excl. } \\
\text { such products planed, sanded, or end-jointed) }\end{array}$ \\
\hline 44072995 & $\begin{array}{l}\text { Abura, afrormosia, ako, andiroba, aningré, avodiré, balau, bossé clair, bossé foncé, cativo, cedro, dabema, } \\
\text { doussié, framiré, freijo, fromager, fuma, geronggang, ipé, jaboty, jequitiba, kosipo, kotibé, koto, louro, } \\
\text { maçaranduba, mahogany (excl. "Swwietenia spp."), mandioqueira, mengkulang, merawan, merpauh, } \\
\text { mersawa, moabi, niangon, nyatoh, onzabili, orey, ovengkol, ozigo, padauk, paldao, palissandre de } \\
\text { Guatemala, pau Amarelo, pau marfim, pulai, punah, quaruba, saqui-saqui, sepetir, sucupira, suren, } \\
\text { tauari, tola, keruing, ramin, kapur, teak, jongkong, merbau, jelutong, kempas, okoumé, obeche, sipo, } \\
\text { acajou d'Afrique, makoré, tiama, mansonia, ilomba, dibétou, limba, azobé, palissandre de Rio, } \\
\text { palissandre de Para, and palissandre de Rose, sawn or chipped lengthwise, sliced or peeled, of a thickness } \\
\text { of }>6 \mathrm{~mm} \text { (excl. end-jointed, planed, and sanded) }\end{array}$ \\
\hline 44072999 & $\begin{array}{l}\text { Abura, afrormosia, ako, andiroba, aningré, avodiré, balau, bossé clair, bossé foncé, cativo, cedro, dabema, } \\
\text { doussié, framiré, freijo, fromager, fuma, geronggang, ipé, jaboty, jequitiba, kosipo, kotibé, koto, louro, } \\
\text { maçaranduba, mahogany (excl. "Swietenia spp."), mengkulang, merawan, merpauh, mersawa, moabi, } \\
\text { niangon, nyatoh, onzabili, orey, ovengkol, ozigo, padauk, paldao, palissandre de Guatemala, pau marfim, } \\
\text { pulai, punah, saqui-saqui, sepetir, sucupira, suren, and tola, sawn or chipped lengthwise, sliced or peeled, } \\
\text { of a thickness }>6 \mathrm{~mm} \text { (excl. finger-jointed, planed, or sanded) }\end{array}$ \\
\hline
\end{tabular}




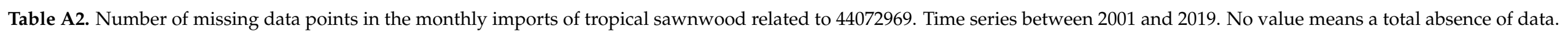

\begin{tabular}{|c|c|c|c|c|c|c|c|c|c|c|c|c|c|c|c|}
\hline & Brazil & Cameroon & Central African Republic & China & Congo & Côte d'Ivoire & Gabon & Ghana & Indonesia & Malaysia & Myanmar & Thailand & Viet Nam & Congo, Democratic Republic of & Liberia \\
\hline Austria & 179 & 207 & 227 & 212 & 215 & 212 & 227 & 165 & 167 & 214 & 223 & 227 & 227 & & \\
\hline Belgium & 0 & 0 & 102 & 181 & 34 & 2 & 6 & 6 & 56 & 1 & 128 & 202 & 225 & 2 & 226 \\
\hline Bulgaria & 227 & 193 & & 226 & 220 & 208 & 225 & 211 & 226 & 227 & & & & 227 & \\
\hline Croatia & 200 & 104 & 227 & 218 & 201 & 169 & 215 & 157 & 194 & 203 & 173 & 223 & 227 & 212 & 227 \\
\hline Czech Republic & 181 & 170 & 226 & 227 & 202 & 225 & & 182 & 167 & 219 & 215 & 226 & & 225 & 227 \\
\hline Denmark & 0 & 49 & 223 & 196 & 49 & 174 & 206 & 85 & 124 & 53 & 94 & 174 & 224 & 202 & 227 \\
\hline Estonia & & 216 & & & 225 & 223 & & 196 & 221 & & 225 & 224 & & 226 & \\
\hline Finland & 206 & 167 & & 222 & 184 & 172 & 220 & 188 & 127 & 132 & 202 & 184 & 227 & 224 & \\
\hline France & 0 & 0 & 132 & 169 & 1 & 6 & 0 & 9 & 46 & 0 & 140 & 210 & 222 & 95 & 185 \\
\hline Greece & 191 & 14 & 227 & 215 & 192 & 2 & 152 & 135 & 171 & 156 & 175 & 217 & & 204 & 225 \\
\hline Hungary & 225 & 219 & & 223 & 224 & 221 & 225 & 214 & 212 & 222 & 225 & & & & \\
\hline Ireland & 206 & 3 & & 219 & 171 & 50 & 216 & 108 & 222 & 215 & & 225 & & 216 & \\
\hline Italy & 65 & 0 & 174 & 103 & 9 & 0 & 0 & 9 & 87 & 6 & 49 & 145 & 213 & 65 & 210 \\
\hline Latvia & 225 & & & & 227 & & & & & & & & & 225 & \\
\hline Lithuania & 207 & 155 & 226 & 220 & 214 & 199 & 226 & 186 & 144 & 215 & 223 & & & 218 & \\
\hline Luxembourg & 227 & 227 & & & & & & & & & & & & 227 & \\
\hline Malta & 221 & 138 & & 224 & 220 & 136 & 222 & 159 & & 226 & 226 & 223 & & 219 & \\
\hline Netherlands & 0 & 0 & 218 & 205 & 96 & 14 & 39 & 54 & 75 & 0 & 114 & 129 & 226 & 125 & 223 \\
\hline $\begin{array}{l}\text { Poland } \\
\text { Pas }\end{array}$ & 125 & 111 & 221 & 219 & 79 & 112 & 171 & 154 & 82 & 138 & 148 & 220 & & 187 & \\
\hline Portugal & 0 & 1 & 200 & 224 & 33 & 77 & 14 & 193 & 222 & 225 & 223 & & & 52 & 227 \\
\hline Slovenia & 199 & 191 & 226 & 221 & 222 & 212 & 224 & 211 & 211 & 222 & 180 & 224 & 227 & 220 & 227 \\
\hline Spain & 2 & 0 & 99 & 200 & 21 & 4 & 39 & 83 & 146 & 186 & 186 & 211 & & 99 & 222 \\
\hline Sweden & 172 & 201 & & 205 & 202 & 214 & 222 & 185 & 126 & 108 & 110 & 192 & 226 & & \\
\hline Utd. Kingdom & 119 & 0 & 206 & 193 & 26 & 2 & 198 & 0 & 116 & 0 & 145 & 206 & 227 & 84 & 225 \\
\hline
\end{tabular}


Table A3. Average yearly imports of tropical sawnwood related to 44072969 over the period 2010-2019 in thousand euros.

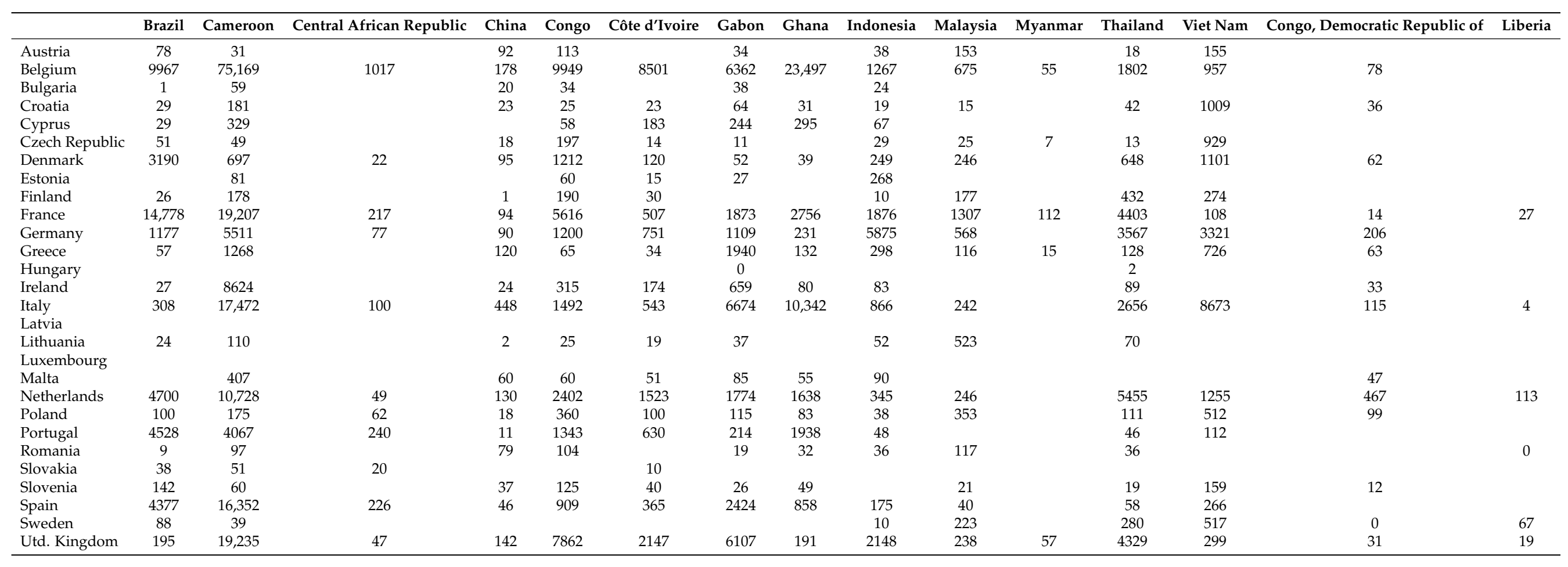


Table A4. Augmented Dickey-Fuller test of the monthly price series of tropical sawnwood over the period 2001-2013. Prices are transformed to natural logarithms. I(1) indicate where the null hypothesis of stationarity is rejected for $p$-values above 0.05 .

\begin{tabular}{|c|c|c|c|c|c|c|}
\hline Reporter & Partner T & ADF Test & Lag Order & $p$ Value & Stationarity & $\mathbf{N}$ \\
\hline Belgium & Côte d'Ivoire & -4.595 & 5 & 0.010 & $\mathrm{I}(0)$ & 146 \\
\hline France & Gabon & -4.386 & 5 & 0.010 & $\mathrm{I}(0)$ & 146 \\
\hline Ireland & Cameroon & -4.238 & 5 & 0.010 & $\mathrm{I}(0)$ & 146 \\
\hline Italy & Ghana & -4.170 & 5 & 0.010 & $\mathrm{I}(0)$ & 146 \\
\hline Denmark & Brazil & -4.080 & 5 & 0.010 & $\mathrm{I}(0)$ & 146 \\
\hline Germany & Malaysia & -4.040 & 5 & 0.010 & $\mathrm{I}(0)$ & 146 \\
\hline Utd. Kingdom & Ghana & -3.997 & 5 & 0.011 & $\mathrm{I}(0)$ & 146 \\
\hline Portugal & Gabon & -3.942 & 5 & 0.014 & $\mathrm{I}(0)$ & 146 \\
\hline Germany & Ghana & -3.914 & 5 & 0.015 & $\mathrm{I}(0)$ & 146 \\
\hline Italy & Congo & -3.880 & 5 & 0.017 & $\mathrm{I}(0)$ & 146 \\
\hline Greece & Cameroon & -3.851 & 5 & 0.018 & $\mathrm{I}(0)$ & 146 \\
\hline France & Côte d'Ivoire & -3.752 & 5 & 0.023 & $\mathrm{I}(0)$ & 146 \\
\hline Belgium & Congo DRC & -3.669 & 5 & 0.030 & $\mathrm{I}(0)$ & 146 \\
\hline France & Brazil & -3.630 & 5 & 0.033 & $\mathrm{I}(0)$ & 146 \\
\hline Utd. Kingdom & Malaysia & -3.591 & 5 & 0.037 & $\mathrm{I}(0)$ & 146 \\
\hline Germany & Cameroon & -3.568 & 5 & 0.039 & $\mathrm{I}(0)$ & 146 \\
\hline Italy & Malaysia & -3.562 & 5 & 0.039 & $\mathrm{I}(0)$ & 146 \\
\hline Belgium & Malaysia & -3.548 & 5 & 0.041 & $\mathrm{I}(0)$ & 146 \\
\hline Utd. Kingdom & Côte d'Ivoire & -3.543 & 5 & 0.041 & $\mathrm{I}(0)$ & 146 \\
\hline Netherlands & Brazil & -3.501 & 5 & 0.045 & $\mathrm{I}(0)$ & 146 \\
\hline Italy & Cameroon & -3.452 & 5 & 0.049 & $\mathrm{I}(0)$ & 146 \\
\hline Spain & Cameroon & -3.412 & 5 & 0.055 & $\mathrm{I}(1)$ & 146 \\
\hline France & Congo & -3.380 & 5 & 0.061 & $\mathrm{I}(1)$ & 146 \\
\hline France & Malaysia & -3.334 & 5 & 0.068 & $\mathrm{I}(1)$ & 146 \\
\hline Spain & Brazil & -3.198 & 5 & 0.091 & $\mathrm{I}(1)$ & 146 \\
\hline Belgium & Ghana & -3.150 & 5 & 0.099 & $\mathrm{I}(1)$ & 146 \\
\hline Belgium & Brazil & -3.082 & 5 & 0.126 & $\mathrm{I}(1)$ & 146 \\
\hline Greece & Côte d'Ivoire & -2.839 & 5 & 0.227 & $\mathrm{I}(1)$ & 146 \\
\hline Netherlands & Côte d'Ivoire & -2.748 & 5 & 0.265 & $\mathrm{I}(1)$ & 146 \\
\hline Netherlands & Cameroon & -2.700 & 5 & 0.285 & $\mathrm{I}(1)$ & 146 \\
\hline Spain & Côte d'Ivoire & -2.686 & 5 & 0.291 & $\mathrm{I}(1)$ & 146 \\
\hline France & Ghana & -2.659 & 5 & 0.302 & $\mathrm{I}(1)$ & 146 \\
\hline Belgium & Gabon & -2.510 & 5 & 0.364 & $\mathrm{I}(1)$ & 146 \\
\hline Netherlands & Malaysia & -2.315 & 5 & 0.445 & $\mathrm{I}(1)$ & 146 \\
\hline Portugal & Brazil & -2.252 & 5 & 0.472 & $\mathrm{I}(1)$ & 146 \\
\hline Italy & Gabon & -2.172 & 5 & 0.505 & $\mathrm{I}(1)$ & 146 \\
\hline Utd. Kingdom & Cameroon & -2.143 & 5 & 0.517 & $\mathrm{I}(1)$ & 146 \\
\hline Italy & Côte d'Ivoire & -2.048 & 5 & 0.556 & $\mathrm{I}(1)$ & 146 \\
\hline France & Cameroon & -1.949 & 5 & 0.598 & $\mathrm{I}(1)$ & 146 \\
\hline Portugal & Cameroon & -1.915 & 5 & 0.612 & $\mathrm{I}(1)$ & 146 \\
\hline Belgium & Cameroon & -1.897 & 5 & 0.619 & $\mathrm{I}(1)$ & 146 \\
\hline
\end{tabular}

Table A5. Augmented Dickey-Fuller test of the monthly price series of oak sawnwood over the period 2001-2013. Prices are transformed to natural logarithms. I(1) indicate where the null hypothesis of stationarity is rejected for $p$-values above 0.05 .

\begin{tabular}{|c|c|c|c|c|c|c|}
\hline Reporter & Partner $\mathrm{T}$ & ADF Test & Lag Order & $p$ Value & Stationarity & $\mathbf{N}$ \\
\hline Greece & United States & -3.729 & 5 & 0.024 & $\mathrm{I}(0)$ & 146 \\
\hline Portugal & United States & -3.716 & 5 & 0.025 & $\mathrm{I}(0)$ & 146 \\
\hline Belgium & United States & -3.613 & 5 & 0.035 & $\mathrm{I}(0)$ & 146 \\
\hline Utd. Kingdom & United States & -3.540 & 5 & 0.041 & $\mathrm{I}(0)$ & 146 \\
\hline Spain & United States & -3.445 & 5 & 0.050 & $\mathrm{I}(0)$ & 146 \\
\hline Italy & United States & -3.223 & 5 & 0.087 & $\mathrm{I}(1)$ & 146 \\
\hline Ireland & United States & -3.122 & 5 & 0.109 & $\mathrm{I}(1)$ & 146 \\
\hline Germany & United States & -2.943 & 5 & 0.184 & $\mathrm{I}(1)$ & 146 \\
\hline France & United States & -2.897 & 5 & 0.203 & $\mathrm{I}(1)$ & 146 \\
\hline Denmark & United States & -2.623 & 5 & 0.317 & $\mathrm{I}(1)$ & 146 \\
\hline Netherlands & United States & -2.446 & 5 & 0.391 & $\mathrm{I}(1)$ & 146 \\
\hline
\end{tabular}




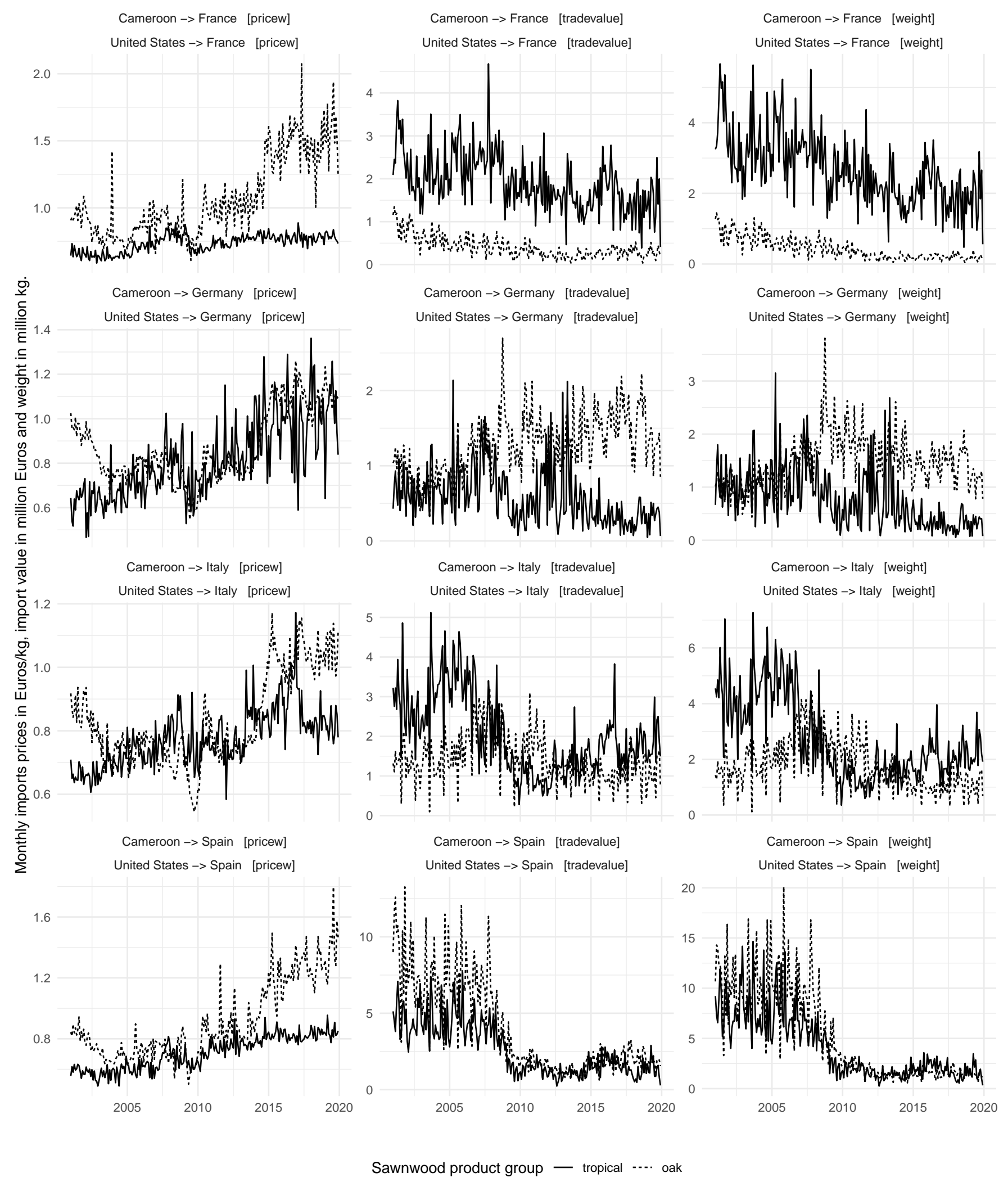

Figure A3. Comparison of tropical sawnwood imports from Cameroon and oak sawnwood imports the United States. Tropical products related to the CN code 44072969 were used in the cointegration analysis. 


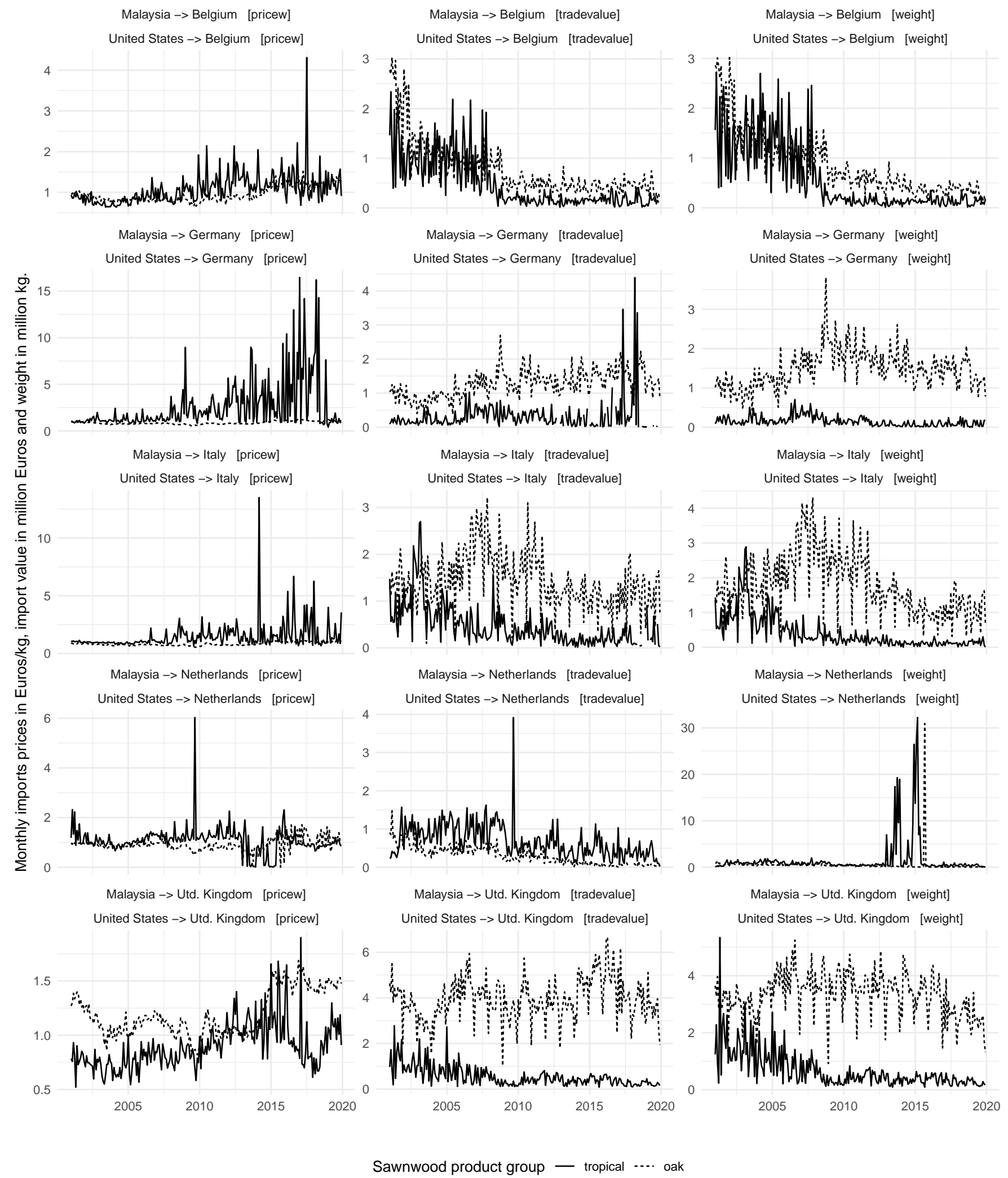

Figure A4. Comparison of tropical sawnwood imports from Malaysia and oak sawn wood imports from the United States. 


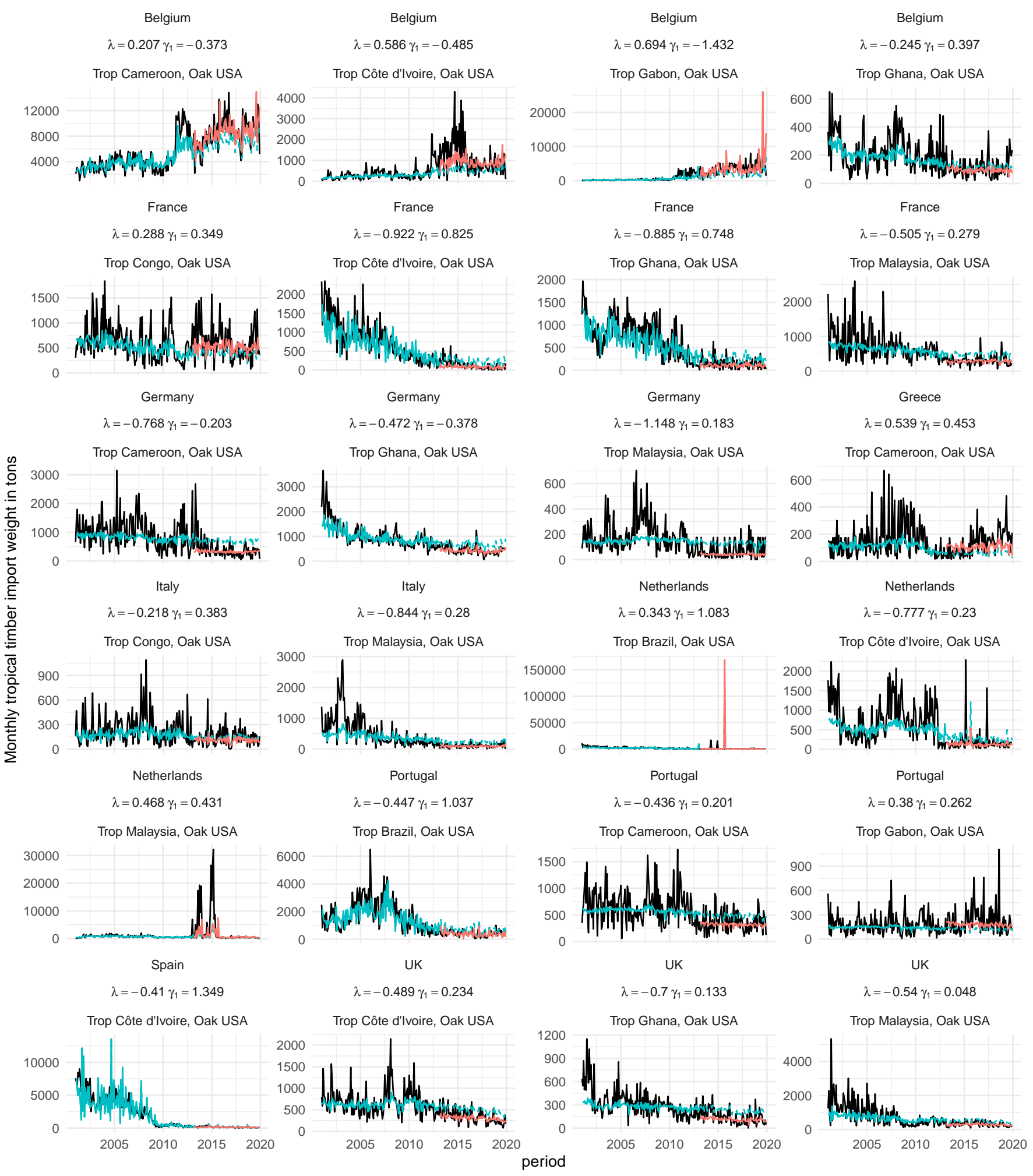

Predicted values with respect to the EUTR shock date - after — before

Figure A5. Observed versus predicted tropical sawnwood import weights based on the shock model. Only country pairs with absolute values of lambda greater than 0.2 are displayed here. 
Table A6. Descriptive statistics of the balanced panel of tropical and oak sawnwood import demand over the period 2002-2019. GDP in constant euros of 2015.

\begin{tabular}{ccccccccccc}
\hline & \multicolumn{2}{c}{ Tropical Imports } & \multicolumn{2}{c}{ Tropical Prices } & \multicolumn{2}{c}{ Oak Imports } & \multicolumn{2}{c}{ Oak Prices } & \multicolumn{2}{c}{ GDP } \\
\cline { 2 - 11 } Reporter & \multicolumn{1}{c}{$\mathbf{1 0 0 0}$ tons/year } & \multicolumn{2}{c}{ Euros/Ton } & $\mathbf{1 0 0 0}$ tons/year & Euros/Ton & \multicolumn{2}{c}{ Billion Euros } \\
\cline { 2 - 12 } & min & max & min & max & min & max & min & max & min & max \\
\hline Austria & 1 & 7 & 855 & 1851 & 48 & 114 & 350 & 722 & 289 & 374 \\
Belgium & 54 & 250 & 668 & 1172 & 11 & 85 & 553 & 2943 & 339 & 444 \\
Bulgaria & 0 & 1 & 616 & 1489 & 1 & 18 & 247 & 581 & 30 & 52 \\
Croatia & 1 & 3 & 738 & 2778 & 4 & 53 & 294 & 612 & 38 & 51 \\
Czech Republic & 1 & 2 & 706 & 3488 & 2 & 24 & 403 & 4037 & 119 & 193 \\
Denmark & 9 & 25 & 859 & 1840 & 7 & 23 & 857 & 1295 & 240 & 305 \\
Estonia & 0 & 1 & 958 & 2549 & 1 & 9 & 452 & 1010 & 14 & 25 \\
Finland & 0 & 4 & 1178 & 3028 & 4 & 23 & 724 & 1412 & 184 & 230 \\
France & 49 & 206 & 584 & 933 & 9 & 31 & 724 & 2859 & 1902 & 2349 \\
Germany & 28 & 85 & 738 & 1476 & 64 & 97 & 422 & 959 & 2575 & 3232 \\
Greece & 2 & 11 & 756 & 1540 & 4 & 40 & 535 & 872 & 175 & 240 \\
Hungary & 0 & 1 & 743 & 1597 & 12 & 39 & 158 & 625 & 90 & 132 \\
Ireland & 5 & 42 & 668 & 1154 & 3 & 13 & 1001 & 1583 & 160 & 335 \\
Italy & 46 & 167 & 735 & 1264 & 99 & 180 & 507 & 760 & 1643 & 1795 \\
Latvia & 0 & 0 & 930 & 13,865 & 1 & 7 & 353 & 1255 & 16 & 28 \\
Lithuania & 0 & 3 & 491 & 1662 & 9 & 91 & 320 & 639 & 23 & 43 \\
Netherlands & 54 & 247 & 212 & 986 & 29 & 532 & 85 & 1383 & 596 & 755 \\
Poland & 1 & 14 & 799 & 1693 & 40 & 116 & 229 & 503 & 262 & 513 \\
Portugal & 13 & 62 & 491 & 769 & 13 & 39 & 645 & 1054 & 175 & 200 \\
Romania & 0 & 1 & 530 & 1544 & 2 & 22 & 324 & 837 & 102 & 196 \\
Slovenia & 0 & 1 & 1188 & 4646 & 16 & 42 & 299 & 741 & 31 & 45 \\
Spain & 26 & 257 & 557 & 963 & 25 & 165 & 557 & 1078 & 935 & 1194 \\
Sweden & 0 & 11 & 918 & 5419 & 5 & 54 & 661 & 1354 & 341 & 492 \\
Utd. Kingdom & 43 & 96 & 689 & 1183 & 62 & 106 & 706 & 1510 & 2143 & 2806 \\
\hline
\end{tabular}



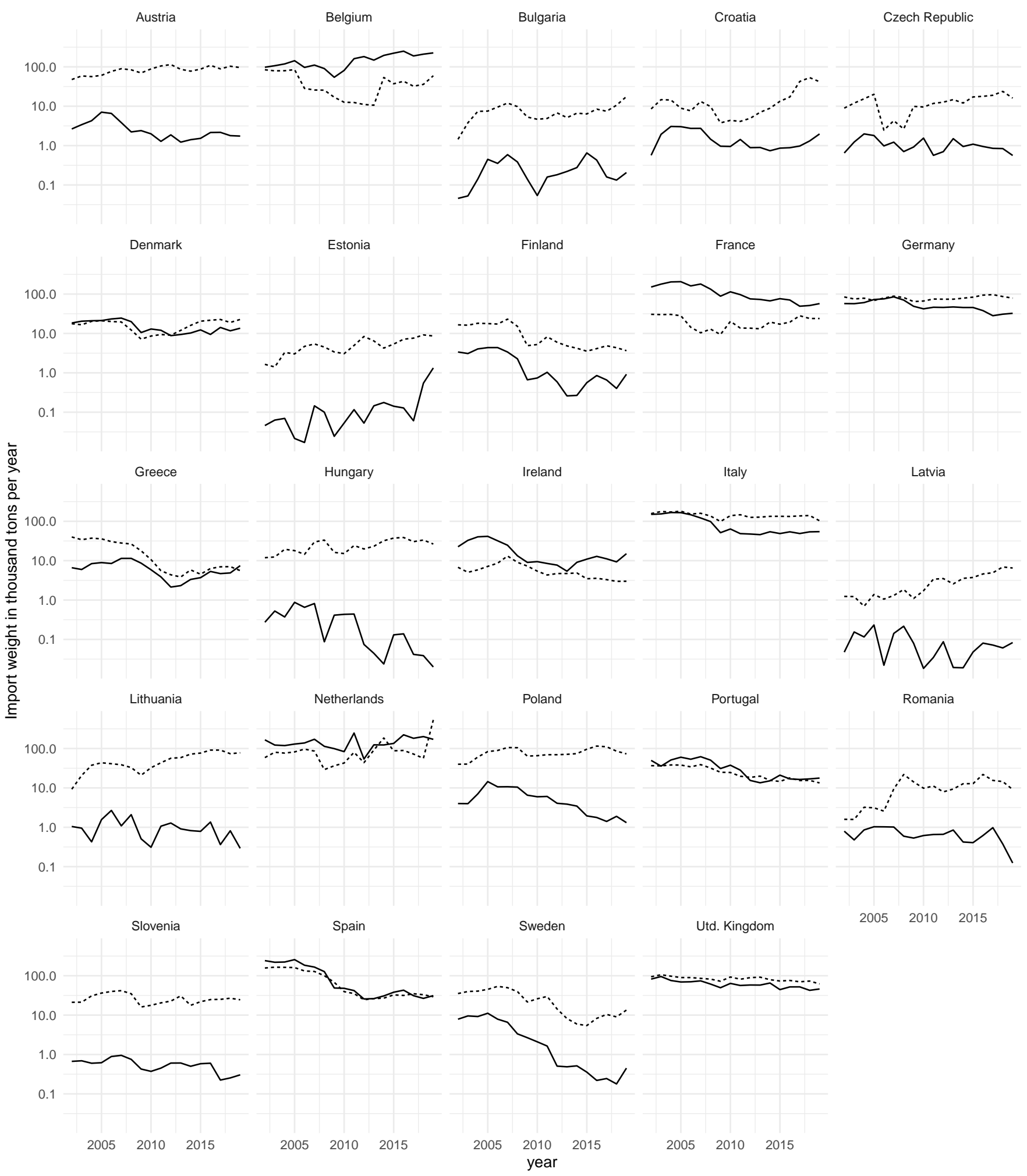

Utd. Kingdom

$$
\text { Sawnwood product group }- \text { tropical } \cdots \cdot \text { oak }
$$

Figure A6. Tropical sawnwood and oak sanwood imports from the balanced panel dataset used in the demand model. 


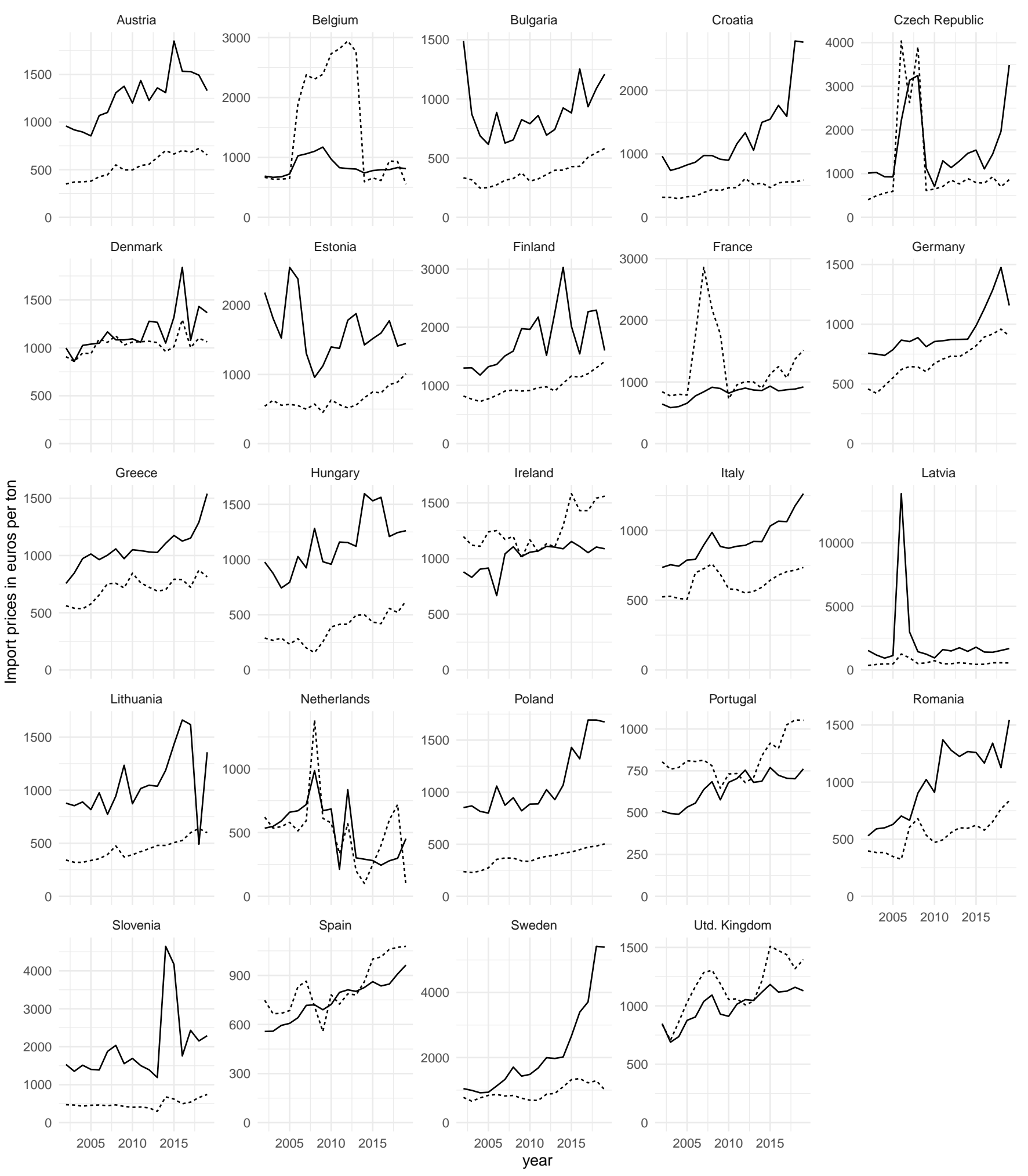

Sawnwood product group - tropical $\cdots$... oak

Figure A7. Tropical sawnwood and oak sawnwood prices from the balanced panel dataset used in the demand model. 
Table A7. Augmented Dickey Fuller tests of the individual time series from the balanced panel dataset.

\begin{tabular}{ccccc}
\hline Reporter & Lweight_Trop & Lpricew_Trop & Lpricew_oak & Lgdp_Const_Eur \\
\hline Austria & $0.542 \mathrm{I}(1)$ & $0.704 \mathrm{I}(1)$ & $0.859 \mathrm{I}(1)$ & $0.464 \mathrm{I}(1)$ \\
Belgium & $0.645 \mathrm{I}(1)$ & $0.211 \mathrm{I}(1)$ & $0.635 \mathrm{I}(1)$ & $0.433 \mathrm{I}(1)$ \\
Bulgaria & $0.178 \mathrm{I}(1)$ & $0.199 \mathrm{I}(1)$ & $0.360 \mathrm{I}(1)$ & $0.237 \mathrm{I}(1)$ \\
Croatia & $0.962 \mathrm{I}(1)$ & $0.978 \mathrm{I}(1)$ & $0.632 \mathrm{I}(1)$ & $0.446 \mathrm{I}(1)$ \\
Czech Republic & $0.495 \mathrm{I}(1)$ & $0.427 \mathrm{I}(1)$ & $0.051 \mathrm{I}(1)$ & $0.229 \mathrm{I}(1)$ \\
Denmark & $0.907 \mathrm{I}(1)$ & $0.335 \mathrm{I}(1)$ & $0.398 \mathrm{I}(1)$ & $0.799 \mathrm{I}(1)$ \\
Estonia & $0.193 \mathrm{I}(1)$ & $0.719 \mathrm{I}(1)$ & $0.963 \mathrm{I}(1)$ & $0.417 \mathrm{I}(1)$ \\
Finland & $0.990 \mathrm{I}(1)$ & $0.949 \mathrm{I}(1)$ & $0.934 \mathrm{I}(1)$ & $0.477 \mathrm{I}(1)$ \\
France & $0.498 \mathrm{I}(1)$ & $0.277 \mathrm{I}(1)$ & $0.242 \mathrm{I}(1)$ & $0.596 \mathrm{I}(1)$ \\
Germany & $0.049 \mathrm{I}(0)$ & $0.122 \mathrm{I}(1)$ & $0.010 \mathrm{I}(0)$ & $0.458 \mathrm{I}(1)$ \\
Greece & $0.833 \mathrm{I}(1)$ & $0.980 \mathrm{I}(1)$ & $0.537 \mathrm{I}(1)$ & $0.437 \mathrm{I}(1)$ \\
Hungary & $0.010 \mathrm{I}(0)$ & $0.461 \mathrm{I}(1)$ & $0.398 \mathrm{I}(1)$ & $0.840 \mathrm{I}(1)$ \\
Ireland & $0.920 \mathrm{I}(1)$ & $0.807 \mathrm{I}(1)$ & $0.859 \mathrm{I}(1)$ & $0.890 \mathrm{I}(1)$ \\
Italy & $0.871 \mathrm{I}(1)$ & $0.817 \mathrm{I}(1)$ & $0.164 \mathrm{I}(1)$ & $0.749 \mathrm{I}(1)$ \\
Latvia & $0.615 \mathrm{I}(1)$ & $0.089 \mathrm{I}(1)$ & $0.323 \mathrm{I}(1)$ & $0.243 \mathrm{I}(1)$ \\
Lithuania & $0.209 \mathrm{I}(1)$ & $0.133 \mathrm{I}(1)$ & $0.305 \mathrm{I}(1)$ & $0.296 \mathrm{I}(1)$ \\
Netherlands & $0.754 \mathrm{I}(1)$ & $0.577 \mathrm{I}(1)$ & $0.261 \mathrm{I}(1)$ & $0.586 \mathrm{I}(1)$ \\
Poland & $0.010 \mathrm{I}(0)$ & $0.934 \mathrm{I}(1)$ & $0.010 \mathrm{I}(0)$ & $0.644 \mathrm{I}(1)$ \\
Portugal & $0.765 \mathrm{I}(1)$ & $0.754 \mathrm{I}(1)$ & $0.976 \mathrm{I}(1)$ & $0.746 \mathrm{I}(1)$ \\
Romania & $0.294 \mathrm{I}(1)$ & $0.956 \mathrm{I}(1)$ & $0.299 \mathrm{I}(1)$ & $0.467 \mathrm{I}(1)$ \\
Slovenia & $0.366 \mathrm{I}(1)$ & $0.404 \mathrm{I}(1)$ & $0.898 \mathrm{I}(1)$ & $0.567 \mathrm{I}(1)$ \\
Spain & $0.926 \mathrm{I}(1)$ & $0.812 \mathrm{I}(1)$ & $0.651 \mathrm{I}(1)$ & $0.370 \mathrm{I}(1)$ \\
Sweden & $0.864 \mathrm{I}(1)$ & $0.871 \mathrm{I}(1)$ & $0.456 \mathrm{I}(1)$ & $0.518 \mathrm{I}(1)$ \\
Utd. Kingdom & $0.434 \mathrm{I}(1)$ & $0.460 \mathrm{I}(1)$ & $0.097 \mathrm{I}(1)$ & $0.471 \mathrm{I}(1)$ \\
\hline
\end{tabular}

Table A8. Maddala and Wu, Levin-Lin-Chu, and Hadri panel stationarity tests of the demand model variables.

\begin{tabular}{cccc}
\hline Variable & Madwu & Levinlin & Hadri \\
\hline lweight_trop & 0.000 & 0.021 & 0.000 \\
& $\mathrm{I}(0)$ & $\mathrm{I}(0)$ & $\mathrm{I}(1)$ \\
lpricew_trop & 0.000 & 0.081 & 0.000 \\
& $\mathrm{I}(0)$ & $\mathrm{I}(1)$ & $\mathrm{I}(1)$ \\
lpricew_oak & 0.003 & 0.070 & 0.000 \\
& $\mathrm{I}(0)$ & $\mathrm{I}(1)$ & $\mathrm{I}(1)$ \\
lgdp_const_eur & 0.625 & 0.020 & 0.000 \\
& $\mathrm{I}(1)$ & $\mathrm{I}(0)$ & $\mathrm{I}(1)$ \\
\hline
\end{tabular}

\section{References}

1. Jonsson, R.; Giurca, A.; Masiero, M.; Pepke, E.; Pettenella, D.; Prestemon, J.; Winkel, G. Assessment of the EU timber regulation and FLEGT action plan. Sci. Policy 2015, 1, 32.

2. European Union. EU Action Plan for Forest Law Enforcement, Governance and Trade (FLEGT). Available online: https: / / eur-lex.europa.eu/legal-content/EN/TXT/?uri=CELEX\%3A52003DC0251 (accessed on 18 February 2021).

3. European Union. Regulation (EU) No 995/2010 of the European Parliament and of the Council of 20 October 2010 Laying Down the Obligations of Operators Who Place Timber and Timber Products on the Market. Available online: https:/ / eur-lex.europa. eu/legal-content/EN/TXT/?uri=CELEX:32010R0995 (accessed on 18 February 2021).

4. Meyfroidt, P.; Rudel, T.K.; Lambin, E.F. Forest transitions, trade, and the global displacement of land use. Proc. Natl. Acad. Sci. USA 2010, 107, 20917-20922. [CrossRef]

5. Lawson, S.; MacFaul, L. Illegal Logging and Related Trade: Indicators of the Global Response; Chatham House London: London, UK, 2010. 
6. Prestemon, J.P. The impacts of the Lacey Act Amendment of 2008 on U.S. hardwood lumber and hardwood plywood imports. For. Policy Econ. 2015, 50, 31-44. [CrossRef]

7. Giurca, A.; Jonsson, R. The opinions of some stakeholders on the European Union Timber Regulation (EUTR): An analysis of secondary sources. iFor. Biogeosci. For. 2015, 8, 681. [CrossRef]

8. ITTO. Market Information Service. Available online: www.itto.int/market_information_service (accessed on 1 October 2018).

9. FLEGT IMM. Substitution, Economic Crisis and Diversion of Supply, Main Drivers of EU Tropical Timber Market Decline. Available online: https: / / www.flegtimm.eu/index.php?view=article\&id=109:imm-survey-substitution-economic-crisis-anddiversion-of-supply-main-drivers-of-eu-timber-market-decline\&catid=67 (accessed on 18 February 2021).

10. ITTO. Tropical Timber Market Report. Volume 21 Number 13. Available online: https://www.itto.int/files/user/mis/MIS_1-15 July2017.pdf (accessed on 16 February 2021).

11. Gan, J.; Cerutti, P.O.; Masiero, M.; Pettenella, D.; Andrighetto, N.; Dawson, T. Quantifying illegal logging and related timber trade. IUFRO World Ser. 2016, 35, 37-59.

12. Turner, J.A.; Buongiorno, J. Estimating price and income elasticities of demand for imports of forest products from panel data. Scand. J. For. Res. 2004, 19, 358-373. [CrossRef]

13. Houthakker, H.S. New Evidence on Demand Elasticities. Econometrica 1965, 33, 277-288. [CrossRef]

14. Tajdini, A.; Tavakkoli, A.; Latibari, A.J.; Roohnia, M.; Tayeb, S.A. Application of simultaneous equations model to estimate particle board demand and supply. BioResources 2011, 6, 3199-3209.

15. Toppinen, A. Incorporating Cointegration Relations in a Short-Run Model of the Finnish Sawlog Market. Can. J. For. Res. 2011, 28, 291-298. [CrossRef]

16. Chas-Amil, M.L.; Buongiorno, J. The demand for paper and paperboard: Econometric models for the European Union. Appl. Econ. 2000, 32, 987-999. [CrossRef]

17. Kangas, K.; Baudin, A. Modelling and Projections of Forest Products Demand, Supply and Trade in Europe; United Nations: Geneva, Switzerland, 2003; Volume 30.

18. Eurostat. RAMON-Reference And Management of Nomenclatures. Available online: https://ec.europa.eu/eurostat/ramon/ relations /index.cfm?TargetUrl=LST_REL (accessed on 1 July 2020).

19. Eurostat. Annual National Accounts (nama10). Available online: https://ec.europa.eu/eurostat/cache/metadata/en/nama10_ esms.htm (accessed on 1 March 2020).

20. Heiss, F. Using R for Introductory Econometrics; Florian Heiss: Düsseldorf, Germany, 2016; pp. $216-217$.

21. Giurca, A.; Jonsson, R.; Rinaldi, F.; Priyadi, H. Ambiguity in timber trade regarding efforts to combat illegal logging: Potential impacts on trade between South-East Asia and Europe. Forests 2013, 4, 730-750. [CrossRef] 